*For correspondence: carmelas@me.com (CS); peter@ walterlab.ucsf.edu (PW)

${ }^{\dagger}$ These authors contributed equally to this work

Present address: ${ }^{\ddagger}$ Calico LLC, South San Francisco, United States

Competing interests:

See page 24

Funding: See page 25

Received: 04 March 2015 Accepted: 13 April 2015 Published: 15 April 2015

Reviewing editor: Jeffery $\mathrm{W}$ Kelly, Scripps Research Institute, United States

(c) Copyright Sidrauski et al. This article is distributed under the terms of the Creative Commons Attribution License, which permits unrestricted use and redistribution provided that the original author and source are credited.

\section{Pharmacological dimerization and activation of the exchange factor elF2B antagonizes the integrated stress response}

\author{
Carmela Sidrauski ${ }^{1,2 \star+\neq}$, Jordan C Tsai ${ }^{1,2+}$, Martin Kampmann ${ }^{2,3}$, Brian R Hearn ${ }^{4,5}$, \\ Punitha Vedantham ${ }^{4,5}$, Priyadarshini Jaishankar ${ }^{4,5}$, Masaaki Sokabe ${ }^{6}$, \\ Aaron S Mendez ${ }^{2,3}$, Billy W Newton7, Edward L Tang7,8, Erik Verschueren7, \\ Jeffrey R Johnson ${ }^{7,8}$, Nevan J Krogan ${ }^{7,8}$, Christopher S Fraser 6 , \\ Jonathan S Weissman ${ }^{2,3}$, Adam R Renslo4,5, Peter Walter ${ }^{1,2 *}$
}

'Department of Biochemistry and Biophysics, University of California, San Francisco, San Francisco, United States; ${ }^{2}$ Howard Hughes Medical Institution, University of California, San Francisco, San Francisco, United States; ${ }^{3}$ Department of Cellular and Molecular Pharmacology, University of California, San Francisco, San Francisco, United States; ${ }^{4}$ Department of Pharmaceutical Chemistry, University of California, San Francisco, San Francisco, United States; ${ }^{5}$ Small Molecule Discovery Center, University of California, San Francisco, San Francisco, United States; ${ }^{6}$ Department of Molecular and Cellular Biology, College of Biological Sciences, University of California, Davis, Davis, United States; ${ }^{7}$ QB3, California Institute for Quantitative Biosciences, University of California, San Francisco, San Francisco, United States; ${ }^{8}$ Gladstone Institutes, San Francisco, United States

\begin{abstract}
The general translation initiation factor elF2 is a major translational control point. Multiple signaling pathways in the integrated stress response phosphorylate elF2 serine-51, inhibiting nucleotide exchange by elF2B. ISRIB, a potent drug-like small molecule, renders cells insensitive to elF2 $\alpha$ phosphorylation and enhances cognitive function in rodents by blocking longterm depression. ISRIB was identified in a phenotypic cell-based screen, and its mechanism of action remained unknown. We now report that ISRIB is an activator of elF2B. Our reporter-based shRNA screen revealed an elF2B requirement for ISRIB activity. Our results define ISRIB as a symmetric molecule, show ISRIB-mediated stabilization of activated elF2B dimers, and suggest that elF2B4 ( $\delta$-subunit) contributes to the ISRIB binding site. We also developed new ISRIB analogs, improving its $\mathrm{EC}_{50}$ to $600 \mathrm{pM}$ in cell culture. By modulating elF2B function, ISRIB promises to be an invaluable tool in proof-of-principle studies aiming to ameliorate cognitive defects resulting from neurodegenerative diseases.

DOI: 10.7554/eLife.07314.001
\end{abstract}

\section{Introduction}

In the integrated stress response (ISR), phosphorylation of the $\alpha$-subunit of the eukaryotic translation initiation factor elF2 (elF2 $\alpha$-P) at serine-51 acts as a major regulatory step that controls the rate of translation initiation. Four distinct elF $2 \alpha$ kinases can catalyze phosphorylation at this single residue, each acting in response to different cellular stress conditions: PERK senses accumulation of unfolded polypeptides in the lumen of the endoplasmic reticulum (ER), GCN2 responds to amino acid starvation 
eLife digest Proteins are often described as life's 'workhorse' molecules, and cells must be able to build new proteins to stay alive. This ability is also vital for storing new memories. A protein called elF2 carries out a critical step in the process that cells use to make proteins; and a decrease in the activity of elF2 has been linked with memory loss in diseases such as Parkinson's and Alzheimer's disease.

When a cell experiences stressful conditions-such as virus infection or starvation-it triggers the 'integrated stress response'. This response helps the cell conserve its resources and take corrective steps to restore its normal working conditions. As part of the integrated stress response, an enzyme adds a phosphate group onto elF2. The 'phosphorylated' elF2 blocks protein production, which causes the cell to make fewer proteins. In 2013, researchers revealed that a small drug-like molecule, called ISRIB, could prevent this decline in protein production following elF2 phosphorylation; and when ISRIB was administered to mice and rats, it enhanced their long-term memories. However, this early work did not identify the molecule that is targeted by ISRIB.

Now Sidrauski, Tsai et al._-including many of researchers involved in the 2013 work-have used a combination of techniques including genetics, chemistry and biochemistry to reveal the target of ISRIB. The experiments show that ISRIB's molecular target is a protein complex called elF2B.

Artificially reducing the production of elF2B made cells resistant to the effects of ISRIB. The elF2B protein normally works to activate eIF2; Sidrauski, Tsai et al. observed that ISRIB boosts the activity of elF2B and renders it insensitive to blockage by phosphorylated elF2. This in turn increases protein production in the cell.

But how does ISRIB activate elF2B? It was known that two copies of elF2B can bind to each other; and Sidrauski, Tsai et al. found that ISRIB acts by stabilizing these larger protein complexes that are more active and less sensitive to inhibition by phosphorylated elF2. Finally, in further experiments, new versions of ISRIB were synthesized that are ten-times as active as the original molecule inside cells.

Importantly, the discovery that elF2B is the molecular target for ISRIB has recently been independently validated by other researchers, and it looks promising that this discovery will guide future efforts to develop clinically useful drugs to treat memory disorders.

DOI: 10.7554/eLife.07314.002

and UV-light, PKR responds to viral infection, and HRI responds to heme deficiency. Their convergence on the same molecular event leads to a reduction in overall protein synthesis. Concomitant with a decrease in new protein synthesis, preferential translation of a small subset of mRNAs that contain small upstream open reading frames (uORFs) in their $5^{\prime}$ untranslated region is induced (Harding et al., 2003; Wek et al., 2006). ISR-translational targets include the well-known mammalian ATF4 (Activating Transcription Factor 4) and CHOP (a pro-apoptotic transcription factor) (Harding et al., 2000; Vattem and Wek, 2004; Palam et al., 2011). ATF4 regulates genes involved in metabolism and nutrient uptake and was shown to have a cytoprotective role upon stress in many cellular contexts (Ye et al., 2010). ATF4 is also a negative regulator of 'memory genes' and its preferential translation in neurites can transmit a neurodegenerative signal in neurons (Chen et al., 2003; Baleriola et al., 2014). ISR activation leads to preferential translation of key regulatory molecules and thus its level and duration of induction must be tightly regulated. Cells ensure that the effects of elF $2 \alpha-\mathrm{P}$ are transient by also activating a negative feedback loop. This is accomplished by GADD34 induction, which encodes the regulatory subunit of the elF2 $\alpha$ phosphatase (Lee et al., 2009). GADD34 induction leads to a reduction of elF2 $\alpha-P$, allowing cells to restore translation (Novoa et al., 2001).

elF2 is a trimeric complex (comprised of $\alpha, \beta$ and $\gamma$ subunits) that binds to both GTP and the initiator methionyl tRNA (Met-tRNA $A_{i}$ ) to form a ternary complex (elF2•GTP•Met-tRNA $A_{i}$ ). After engaging the 40S ribosomal subunit at an AUG start codon recognized by Met-tRNA $A_{i}$, GTP is hydrolyzed by the GTPase activating protein (GAP) elF5, and the 60S ribosomal subunit joins to form a complete $80 \mathrm{~S}$ ribosome ready for polypeptide elongation. elF2 $\bullet$ GDP is released, and elF2 must then be reloaded with GTP to enter another round of ternary complex formation (Hinnebusch and Lorsch, 2012). In addition to being a GAP for elF2, elF5 is also a GDP dissociation inhibitor that prevents GDP release from elF2 (Jennings and Pavitt, 2015). The exchange of GDP with GTP in elF2 is catalyzed by its dedicated 
guanine nucleotide exchange factor (GEF) elF2B, which has the dual function of catalyzing the release of both elF5 and GDP (Jennings et al., 2013). elF2B is a complex molecular machine, composed of five different subunits, elF2B1 through elF2B5, also called the $\alpha, \beta, \gamma, \delta$, and $\varepsilon$ subunits. elF2B5 catalyzes the GDP/GTP exchange reaction and, together with a partially homologous subunit elF2B3, constitutes the 'catalytic core' (Williams et alo, 2001). The three remaining subunits (elF2B1, elF2B2, and elF2B4) are also highly homologous to one another and form a 'regulatory subcomplex' that provides binding sites for elF2B's substrate elF2 (Dev et alo, 2010). When phosphorylated on Ser-51, elF2 $\alpha$-P dissociates more slowly from the elF2B regulatory sub-complex and locks elF2B into an inactive state (Krishnamoorthy et al., 2001). Phosphorylation thus renders elF2 an inhibitor of its own GEF. Because elF2 is more abundant than elF2B, a small amount of elF2 $\alpha-P$ is sufficient to sequester a large proportion of available elF2B, leading to a substantial reduction in overall protein synthesis.

Using a cell-based high-throughput screen, we recently identified a small molecule, ISRIB (for integrated stress response inhibitor) that renders cells resistant to the inhibitory effects of elF2 $\alpha-P$. ISRIB, the only bona fide ISR inhibitor identified to date, is a highly potent compound ( $E C_{50}=5 \mathrm{nM}$ in cells) and has good pharmacokinetic properties (Sidrauski et al., 2013). In agreement with the phenotype of genetically modified mice having reduced elF $2 \alpha-P$, we showed that treatment with ISRIB enhances memory consolidation in rodents. Moreover, ISRIB comprehensively and selectively blocked the effects of elF2 $\alpha$ phosphorylation on mRNA translation and triggered rapid stress granule disassembly (Sidrauski et alo, 2015). To date, the molecular target of ISRIB is not known. The fast kinetics of action of ISRIB and the remarkable specificity of its effects in response to elF2 $\alpha$ phosphorylation strongly suggested that its target is a factor that closely interacts with the elF2 translation initiation complex. The existence of elF2B mutations in yeast that, like ISRIB, render cells resistant to elF2 $\alpha$-P led us to propose that elF2B was a likely target of this small molecule (Sidrauski et al., 2013). Here, we draw on clues from two independent approaches, an unbiased genetic screen and structure/activity analyses of ISRIB, to converge on the hypothesis that the mammalian elF2B complex indeed is the molecular target of ISRIB. We demonstrate that a symmetric ISRIB molecule induces or stabilizes elF2B dimerization, increasing its GEF activity and desensitizing it to inhibition by eIF2-P. Thus ISRIB directly modulates the central regulator in the ISR.

\section{Results}

\section{Knockdown of elF2B renders cells resistant to ISRIB}

To identify the molecular target of ISRIB, we conducted a genetic screen for genes whose knockdown modulated the sensitivity of cells to the drug. Using this strategy, we were previously able to pinpoint the molecular targets of cytotoxic compounds and to delineate their mechanism of action (Matheny et al., 2013; Julien et al., 2014). Here, we conducted a reporter-based screen using a sub-library of our next-generation shRNA library targeting 2933 genes involved in aspects of proteostasis. This focused library targets each protein-coding gene with $\sim 25$ independent shRNAs and contains a large set $(>1000)$ of negative-control shRNAs. We have previously shown that the use of such libraries and analysis using a rigorous statistical framework generates robust results from forward genetic screens (Bassik et al., 2013; Kampmann et al., 2013). We screened the shRNA library in a K562 cell line expressing an uORF-ATF4-venus reporter (Figure 1A), similar to the translational reporters that we and others previously used to measure activation of the ISR. In cells bearing this reporter, the venus fluorescent protein is translationally induced upon elF2 $\alpha$ phosphorylation. We chose the K562 cell line for the screen because these cells are non-adherent and allow for efficient fluorescence-activated cell sorting (FACS). Treatment with thapsigargin ( $\mathrm{Tg}$ ), an ER stress inducer that inhibits the ER-localized $\mathrm{Ca}^{2+}$-ATPase, resulted in a sixfold increase in mean fluorescence intensity and, as expected, ISRIB substantially reduced induction of the reporter (Figure 1B). As a first step in the screen, we transduced the reporter cell line with the library and selected shRNA-expressing cells. We next divided the population and induced ER stress with Tg in the presence or absence of ISRIB. To optimize the dynamic range of the screen and to focus on early translational effects elicited by elF $2 \alpha$ phosphorylation, we incubated cells for $7 \mathrm{hr}$, at which time full induction of the reporter was reached. To identify genes whose knockdown resulted in either enhanced or reduced sensitivity to ISRIB, we used a concentration of drug corresponding to the $\mathrm{EC}_{50}(15 \mathrm{nM})$ in this cell type. Cells from each subpopulation (Tg-treated and Tg + ISRIB-treated) were then FACS-sorted to isolate the third of the 


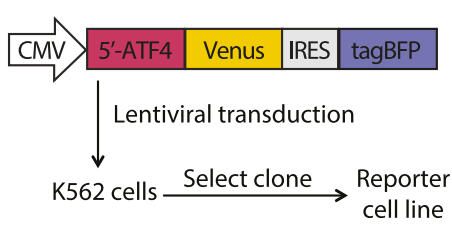

C

D

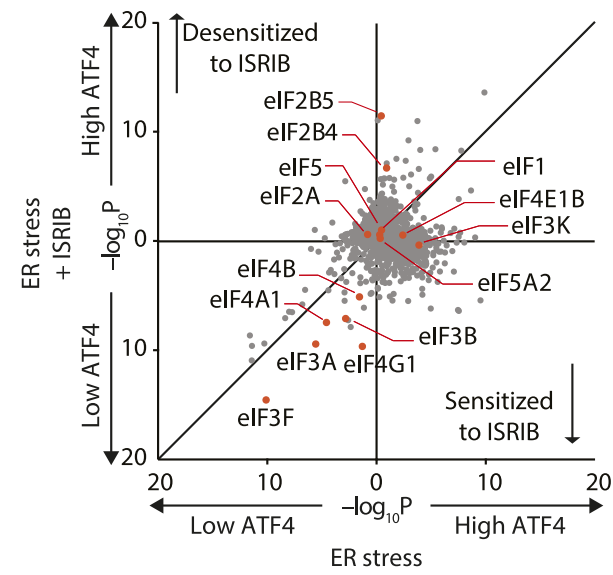

B
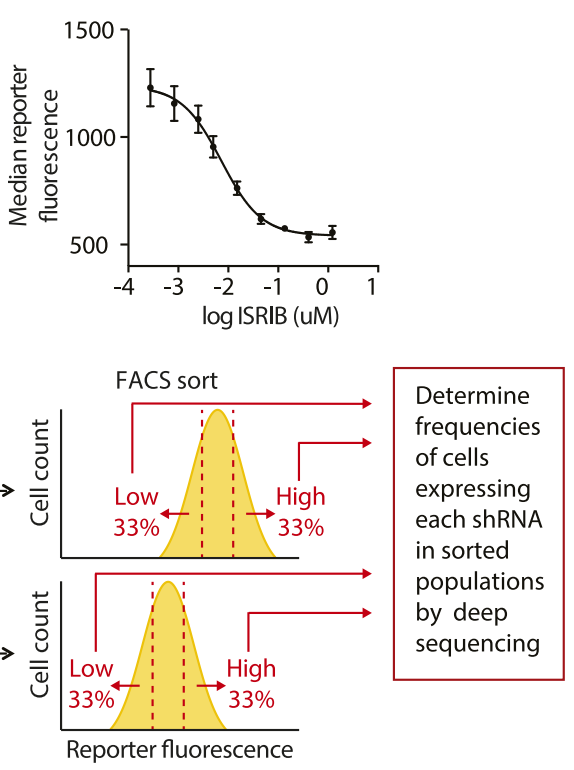

$\mathrm{E}$
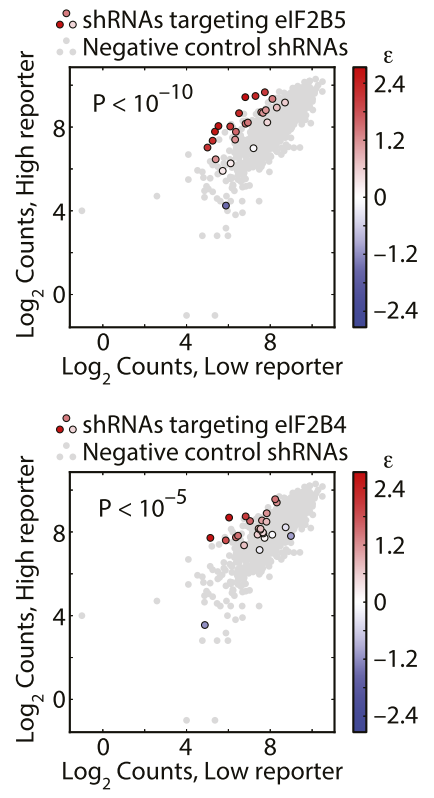

Figure 1. Knockdown of elF2B subunits renders cells more resistant to ISRIB. (A) Schematic representation of the ATF4-venus reporter used for the screen. The $5^{\prime}$ end of the human ATF4 mRNA up to the start codon of the ATF4encoding ORF was fused to venus, followed by the EMCV internal ribosomal entry site (IRES) and BFP and inserted into a lentiviral system. (B) ISRIB reduces activation of the ATF4-venus reporter. K562 cells were incubated with Tg $(300 \mathrm{nM})$ for $6 \mathrm{hr}$ in the presence of different concentrations of ISRIB. Reporter fluorescence was measured by flow cytometry and median values were plotted $(N=3, \pm S D)$. (C) Schematic of the shRNA screen aimed to identify the target ISRIB. K562 cells expressing the screening reporter were transduced with a pooled shRNA library and transduced cells were selected. The population was then divided into two and either treated with $\mathrm{Tg}$ (ER stress) or $\mathrm{Tg}+$ ISRIB (ER stress + ISRIB) for $7 \mathrm{hr}$. Cells were sorted based on their fluorescence (venus) intensity into three bins and the third of the population with the Low and High-reporter levels were collected. Note that the ER stress + ISRIB population had a lower overall fluorescence intensity (median) as ISRIB partially blocks induction of the reporter when added at a concentration corresponding to its $\mathrm{EC}_{50}$ in these cells $(15 \mathrm{nM})$. DNA was extracted from the sorted subpopulations for each treatment and shRNA-encoding cassettes were PCR-amplified and subjected to deep sequencing to determine their frequency. (D) Effect of knockdown of individual genes in the proteostasis library on reporter expression upon ISR induction in the presence and absence of ISRIB. Gene $p$ values for enrichment and depletion were compared between the ER stress ( $x$-axis) vs the ER stress + ISRIB ( $y$-axis) experiments. For each gene, Figure 1. continued on next page 
Figure 1. Continued

a $p$ value was calculated by comparing the distribution of $\log _{2}$ enrichment values for the 25 shRNAs targeting the gene to the negative control shRNAs. (E) The $\log _{2}$ counts for elF2B5 (top panel) or elF2B4 (bottom panel) targeting shRNAs in the High-reporter population (x-axis) vs the Low-reporter population (y-axis) was plotted and color coded based on the $\log _{2}$ enrichment as depicted in the side bar. Red colors indicate a shift towards higher reporter levels, blue colors shifts towards lower reporter levels. Negative control shRNAs in the library are colored grey. DOI: 10.7554/eLife.07314.003

The following source data are available for figure 1:

Source data 1. Sequence of the reporter utilized in the shRNA screen. DOI: 10.7554/eLife.07314.004

Source data 2. Gene p values for the High and Low reporter populations. DOI: 10.7554/eLife.07314.005

population with the lowest reporter expression and the third of the population with the highest reporter expression (see schematic in Figure 1C). To quantify frequencies of cells expressing each shRNA, we isolated genomic DNA from the sorted populations and then PCR-amplified, purified and analyzed by deep-sequencing the shRNA-encoding cassettes. To determine the enrichment or depletion of each shRNA, we compared its frequency in the Low and High reporter populations. For each gene, we calculated a $p$ value by comparing the distribution of $\log _{2}$ enrichment for the 25 shRNAs targeting the gene to the negative control shRNAs. We then plotted $p$ values for each gene determined in ER stressinduced cells in the absence (x-axis) vs the presence (y-axis) of ISRIB (Figure 1D).

The data shown in Figure 1D revealed that knockdown of the majority of the genes in the library did not change the expression of the reporter upon either treatment and thus congregated in the center of the plot. By contrast, knockdown of genes that changed the expression of the reporter to the same degree in both treatments localized to the diagonal. We focused our analysis on genes that when knocked-down in the presence of ISRIB, affected the expression of the reporter selectively. In this plot these genes are displaced along the $y$-axis and encode proteins whose reduced expression modulates the cells' sensitivity to ISRIB. Knockdown of genes that confer resistance to ISRIB lie above the diagonal, while knockdown of genes that confer hypersensitivity to ISRIB lie below it.

Of particular interest was the pronounced effect of the knockdown of (i) two subunits of elF2B, elF2B4 and elF2B5, that significantly reduced the sensitivity $\left(p<1.4 \cdot 10^{-6}\right.$ and $p<2.4 \cdot 10^{-11}$, respectively) and (ii) elF4G1 that significantly enhanced the sensitivity $\left(p<3.4 \cdot 10^{-10}\right)$ of cells to ISRIB, each without affecting induction of the reporter (i.e., no displacement along the $x$-axis). Individual shRNAs targeting either elF2B4 or elF2B5 were enriched in the High reporter population of the ISRIBtreated sample and stood out from the negative control shRNA population (Figure 1E). Knockdown of other translation initiation factors (highlighted in Figure 1D) revealed no effects on ISRIB sensitivity (locating close to the diagonal of the plot). Based on these data and the fact that elF $2 \alpha-P$ is a direct inhibitor of elF2B, we postulated that elF2B is a promising candidate target of ISRIB. Moreover, the data suggest that ISRIB acts as an activator of elF2B: when elF2B levels are reduced, cells become resistant to the effects of ISRIB when there is a lower supply of molecules that can be activated.

\section{Structure-activity relationship of ISRIB suggests a twofold symmetric target}

Structure-activity studies of synthetic ISRIB analogs provided further clues as to the nature of its molecular target in cells. Of particular note is that the progenitor member of this class (ISRIB, also denoted herein as ISRIB-A1, Figure 2A) exhibits twofold rotational symmetry and is bisected longitudinally by a mirror plane. The molecule is thus achiral but can exist as either cis or trans diastereomers, depending on the relative orientation of the side chains at positions 1 and 4 of the cyclohexane ring (Figure 2A, ISRIB-A1 and ISRIB-A2). We previously showed in cell-based assays that the trans-isomer (ISRIB-A1, $\mathrm{EC}_{50}=5 \mathrm{nM}$ ) is $>100$-fold more potent than the cis-isomer (ISRIB-A2, $\mathrm{EC}_{50}>600 \mathrm{nM}$ ). This indicated a preference for an extended binding conformation, with both side chains adopting an equatorial position, as would be expected in the preferred chair conformation of the trans diastereomer (ISRIB-A1) (Sidrauski et al., 2013). By contrast, the cis diastereomer ISRIB-A2 would need to adopt a higher-energy boat-like conformation to project both side chains in pseudoequatorial orientations. Further structure-activity studies revealed that a 1,4-phenyl spacer could reasonably substitute for 1,4-cyclohexyl, although a 10-fold loss in potency was observed (ISRIB-A7, 


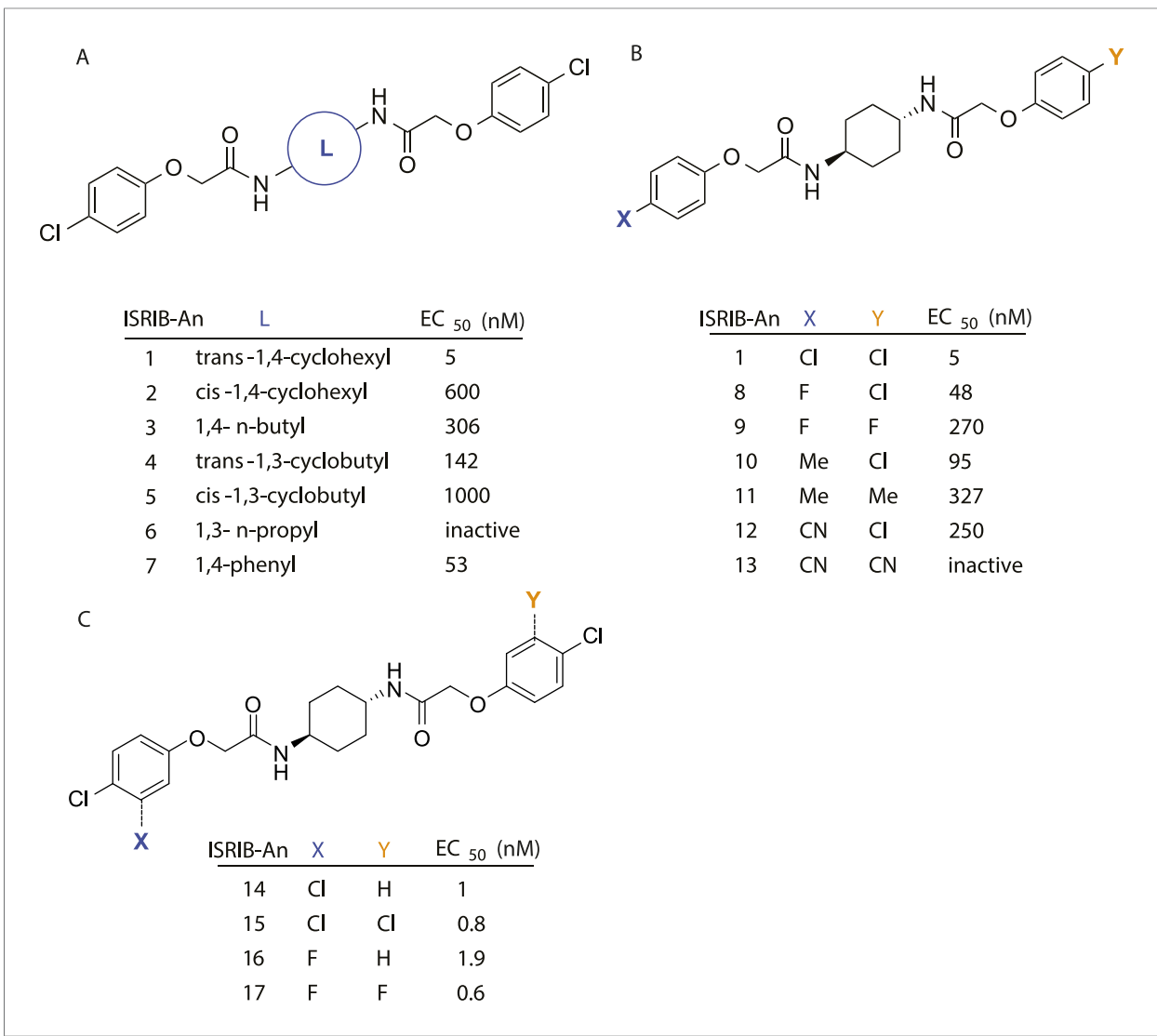

Figure 2. SAR analyses suggest ISRIB interacts with a twofold symmetric target. (A) ISRIB analogs bearing various likers $(L)$ between the pendant side chains and their corresponding $E_{50}$ values. (B) Sequential replacement of the para-chloro substituent ( $\mathrm{X}$ and $\mathrm{Y}$ ) with $\mathrm{F}, \mathrm{Me}$, or $\mathrm{CN}$ on the distal aromatic rings has unfavorable and additive effects on potency. (C) Sequential addition of a meta-substituent $(X$ and $Y$ ) on the distal aromatic rings had favorable and additive effects on potency. Dose response curves of the different ISRIB analogs are shown in Figure 2-figure supplement 1.

DOI: 10.7554/eLife.07314.006

The following figure supplement is available for figure 2:

Figure supplement 1. Activation of the ATF4 luciferase reporter in HEK293T cells was measured. DOI: 10.7554/eLife.07314.007

$\left.\mathrm{EC}_{50}=53 \mathrm{nM}\right)$. Replacement of the 1,4-cyclohexyl ring with cis or trans-1,3-cyclobutyl spacers resulted in a more dramatic loss of potency (ISRIB-A4, EC $50=142 \mathrm{nM}$; ISRIB-A5, $\mathrm{EC}_{50}=1000 \mathrm{nM}$ ), indicating that the distance between the distal aromatic rings in ISRIB analogs is as important as their positioning in space. This distance dependence was also observed in analogs with acyclic spacers (e.g., ISRIB-A3 and ISRIB-A6). Thus, the $n$-butyl linker in ISRIB-A3 (maintaining the spacing of ISRIB-A1) was better tolerated than the shorter n-propyl linker in ISRIB-A6, an analog without measurable activity. The 60fold reduction in the potency of ISRIB-A3 as compared to ISRIB-A1 can be explained by the increased flexibility of the $n$-butyl chain, resulting in a higher entropic cost associated with adopting the conformation required for binding.

Extensive structure-activity relationship (SAR) studies were also carried out on the distal aryl substituents. Overall, we found that the SAR was consistent with the idea that ISRIB analogs bind across a symmetrical interface. Thus, sequential modification of one and then both side chains in ISRIB analogs was additive, both for favorable modifications and for unfavorable modifications. For example, a para-chloro substituent was found to be optimal in ISRIB analogs. Replacing one or both para-chloro substituents with fluoro, methyl, or cyano groups led to predictable deterioration of potencies, with the doubly modified analogs least potent in every case (Figure 2B, compare ISRIB-A8 with A9, ISRIB-A10 with A11 and ISRIB-A12 with A13). Conversely, the addition of a meta-chloro or 
meta-fluoro substituent enhanced the potency of ISRIB analogs, and introducing such modifications on both side chains produced the most potent analogs (Figure 2C, compare ISRIB-A14 with A15, ISRIBA16 with A17). Among these more potent analogs is ISRIB-A17, which is nearly 10-fold more potent than ISRIB-A1, lowering the $\mathrm{EC}_{50}$ into the picomolar range. A full account of our SAR studies will be provided elsewhere but the data presented here demonstrate that the electronics of the phenoxy substituents are important drivers of potency and support the notion that the two halves of ISRIB analogs are engaged in similar recognition events with the target. The most plausible explanation of these findings is that the functional twofold symmetry of ISRIB reflect a target that is likewise twofold symmetric. Taken together, the results obtained by the shRNA screen described above and the recent discovery of elF2B dimers suggest that ISRIB may act by directly binding to elF2B at a twofold symmetric interface that stabilizes it as a dimer (Gordiyenko et alo, 2014; Wortham et al., 2014).

\section{ISRIB promotes dimerization of elF2B in cells}

To test directly whether ISRIB induces or stabilizes the dimeric form of elF2B, we treated cells with or without ISRIB. We prepared extracts in a high-salt buffer to dissociate elF2B from its substrate elF2 and analyzed the lysates by velocity sedimentation on sucrose gradients. In the absence of ISRIB, elF2B (as detected by immunoblotting with antibodies against elF2B4 and elF2B5) migrated predominantly in fractions 3-6 in the gradient, consistent a combined molecular mass of four of its subunits $(225 \mathrm{kDa})$. In the high-salt buffer used, the elF2B complex lacked the elF2B1 subunit, which was found predominantly in fractions 1-3 of the gradient. By contrast, when cells were treated with ISRIB, we observed a substantial shift in sedimentation towards a higher molecular mass (predominantly found in fractions 5-8), demonstrating a substantial increase in complex size. By comparing the relative mobility of elF2B4 and elF2B5 to that of a background band (marked with a red asterisk in the upper panel of Figure 3), the shift in size of elF2B is easily appreciated. The magnitude of the shift is consistent with a doubling in the molecular mass of the complex. Interestingly, in extracts from ISRIB-treated cells, elF2B1 also shifted to the heavier fractions, suggesting that its association with the rest of the complex was stabilized. In contrast to the elF2B subunits, we did not observe a shift in elF3a or elF2 $\alpha$. These data strongly support the notion that ISRIB induces the formation of a stable elF2B dimer.

To determine if elF2B's ostensible increase in molecular mass was due to dimerization of a complete elF2B complex, we used mass spectrometry to validate the shift of all of its five subunits. To this end, we treated cells with ISRIB or with an inactive analog ('ISRIBinact' [ISRIB-A18], Figure 3-figure supplement 1) and subjected extracts to fractionation on sucrose gradients. We used ISRIB inact to control for non-specific hydrophobic interactions of ISRIB with proteins in the extract. We determined the complete protein composition in the fractions in which elF2B peaked in the presence of ISRIB (fractions 6-9, Figure 3-figure supplement 2) by mass spectrometry. This analysis revealed a significant ISRIB-dependent enrichment of all five elF2B subunits (Figure 3B). Notably, eIF2B subunits in ISRIB samples exhibited a characteristic profile in which all subunits collectively peaked in fraction 7. By contrast elF2B subunits in ISRIB inact samples were most abundant in fraction 6 and trailed further into the gradient. As expected, two other large protein complexes, the proteasome (Figure 3B; data shown for subunit PSMD1) and elF3 (Figure 3B; data shown for subunit elF3A), showed no displacement upon ISRIB treatment.

Because the mass spectrometric analysis of the gradient was performed with a non-targeted method, it allowed us to ask whether additional proteins would associate with elF2B potentially contributing to the shift in size. To address this question, we correlated the intensity profiles of all other proteins identified through the analyzed fractions to the sedimentation profile exhibited by a representative subunit, elF2B4. We plotted the correlation coefficient ( $R$-value) for each comparison. We were excited to find that all elF2B subunits (elF2B1, elF2B2, elF2B3, elF2B5) stood out as most strongly correlated to elF2B4, all exhibiting correlation coefficients (R-values) $>0.98$ (Figure 3C), strongly indicating that the increase in molecular mass of elF2B upon ISRIB addition indeed resulted from elF2B dimerization. Moreover, these analyses strongly support the notion that elF2B forms a complete complex upon ISRIB treatment.

\section{ISRIB enhances the thermo-stability of eIF2B4}

To identify the subunit of elF2B targeted by ISRIB, we monitored drug-target engagement, utilizing a cellular extract thermal shift assay (CETSA) (Martinez Molina et al., 2013). This 
A

- ISRIB $\quad$ +ISRIB

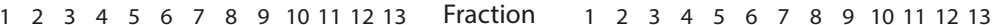

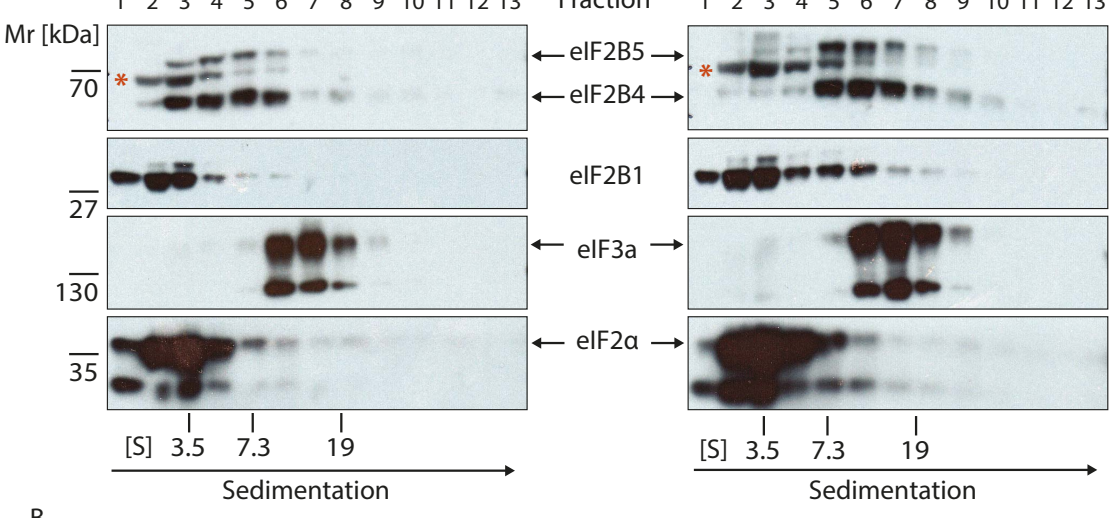

B
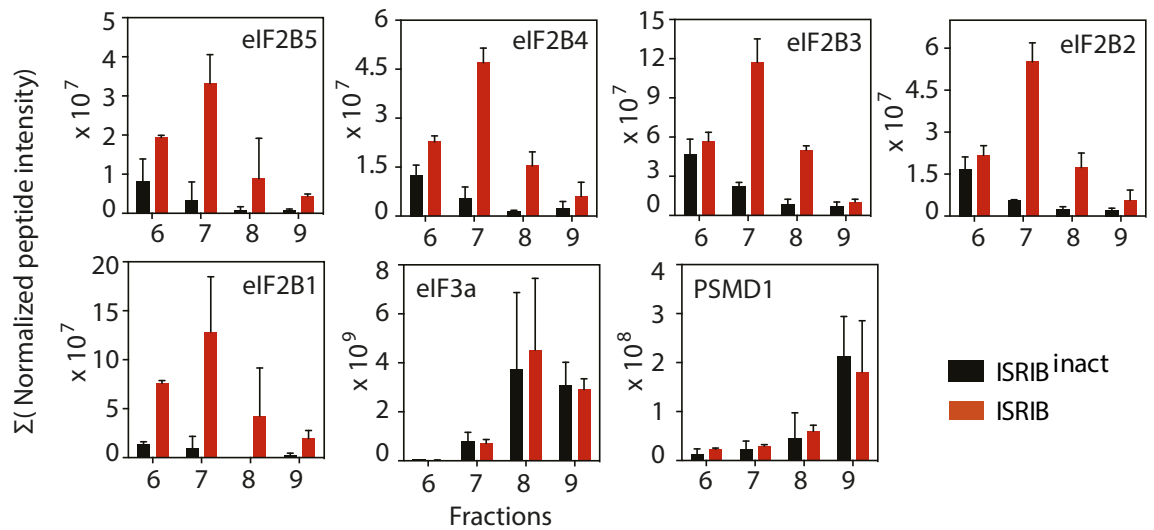

ISRIB inact

- ISRIB

C

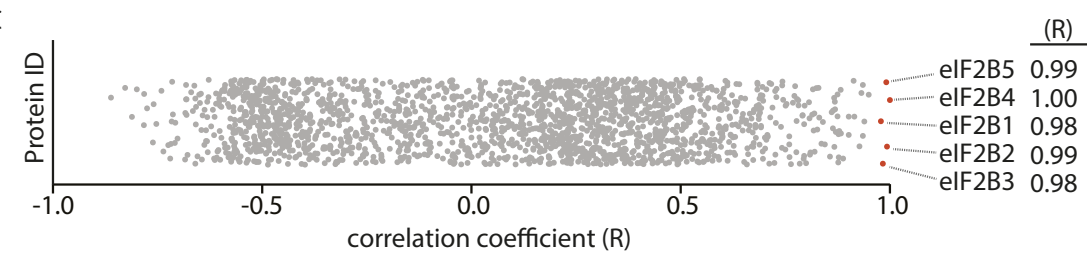

Figure 3. ISRIB induces dimerization of elF2B in cells. (A) HEK293T cells were treated with or without $200 \mathrm{nM}$ ISRIB and clarified lysates were loaded on a 5-20\% sucrose gradient and subjected to centrifugation. 13 equal-size fractions were collected, protein was precipitated and run on a SDS-PAGE gel and immunoblotted with the indicated antibodies. The red asterisk indicates a background band that cross-reacts with the elF2B4 antibody. Sedimentation was from left to right. Gradients were calibrated (in Svedberg units, 'S') with ovalbumin ( $\mathrm{S}=3.5$; $\mathrm{Mr}=44 \mathrm{kD})$; aldolase $(\mathrm{S}=7.3 ; \mathrm{Mr}=158 \mathrm{kD})$ and thyroglobulin $(\mathrm{S}=19 ; \mathrm{Mr}=669 \mathrm{kD})$. Shown is a representative blot ( $N=3$ ). (B) HEK293T cells and lysates were treated with $200 \mathrm{nM}$ ISRIB or $200 \mathrm{nM}$ ISRIB inact (ISRIB-A18; Figure 3-figure supplement 1) and clarified lysates were loaded on a 5-20\% sucrose gradient and subjected to centrifugation. 13 equal sized fractions were collected and fractions 6-9 were precipitated, trypsinized and subjected to mass spectrometric analysis. The sum of the normalized peptide intensity of each elF2B subunit as well as two control proteins, elF3a and PSMD1 in each fraction was plotted. Two biological replicates were analyzed per condition ( $N=2, \pm S E M)$. The number of peptides and peptide intensity in fractions 6-9 for all proteins identified are listed in Figure 3-source data 1. (C) Correlation coefficient (R) of the sum of the normalized peptide intensity profile through fractions 6-9 for each protein identified in the analysis with respect to elF2B4 was plotted. The Correlation coefficient $(\mathrm{R})$ of the sum of the normalized peptide intensity profile with respect to elF2B4 of each protein identified are listed in Figure 3-source data 2.

DOI: 10.7554/eLife.07314.008

Figure 3. continued on next page 
Figure 3. Continued

The following source data and figure supplements are available for figure 3 :

Source data 1. Number of peptides and peptide intensity in fractions 6-9 for all proteins identified. DOI: 10.7554/eLife.07314.009

Source data 2. Correlation coefficient (R) of the sum of the normalized peptide intensity profile through fractions 6-9 with respect to elF2B4 for each protein identified.

DOI: 10.7554/eLife.07314.010

Figure supplement 1. Structures of ISRIB (ISRIB-A1) and ISRIB inact $(I S R I B-A 18)$. DOI: 10.7554/eLife.07314.011

Figure supplement 2. Analysis of the gradients subjected to mass spectrometric analysis in Figure $3 \mathbf{B}$. DOI: 10.7554/eLife.07314.012

method relies on the principle that ligand binding can stabilize protein folding and hence increase the protein's resistance to heat denaturation. To this end, we incubated a cell lysate with and without ISRIB and then heated aliquots to different temperatures, followed by centrifugation to separate soluble from precipitated denatured proteins. We then analyzed the soluble fractions by Western blotting with antibodies against elF2B1, elF2B4 and elF2B5. When the lysate was pre-incubated with ISRIB, we observed an increase in thermal stability of elF2B4 (Figure 4, lanes 4 and 5, arrows). Although slight, the increase was highly reproducible and, as was the case for the analysis of the elF2B shift in the sucrose gradients shown in Figure 3, a background band that cross-reacts with the anti-elF2B4 antibody (red asterisk) provided a convenient internal control for the exclusive stabilization of elF2B4. By contrast, no ISRIB-dependent increase in thermal stability was observed with the two other elF2B subunits analyzed (elF2B1 and elF2B5), or with the translation initiation factors elF2 $\alpha$ or elF3a (Figure 4). This analysis suggests that elF2B subunits act autonomously in this assay, as elF2B4 was stabilized while other subunits denatured and precipitated. We conclude that ISRIB binds elF2B4 eliciting this stabilization.

\section{ISRIB enhances the GEF activity of elF2B}

To explore the functional consequences of ISRIB binding on elF2B's GEF activity, we directly tested its effect on the rate of GDP release from elF2. To this end, we pre-loaded purified elF2 with radioactive

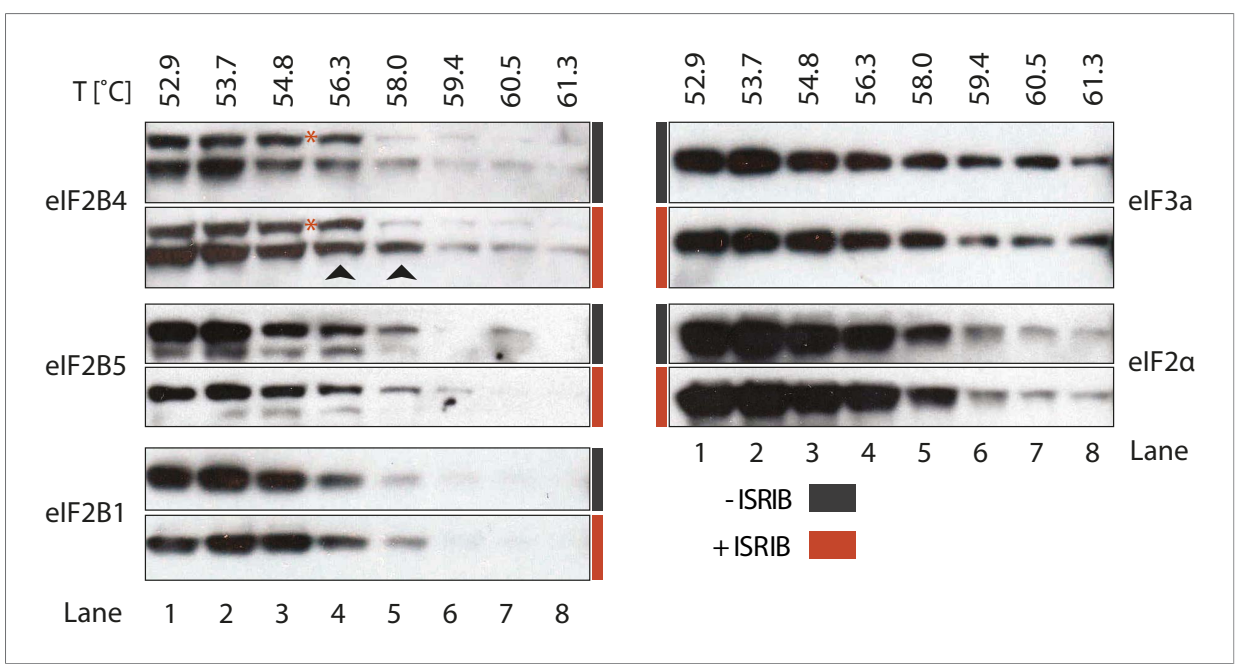

Figure 4. ISRIB enhances the thermo-stability of the regulatory subunit of elF2B. Clarified HEK293 cell lysates were treated with DMSO (-ISRIB) or with $200 \mathrm{nM}$ ISRIB (+ISRIB) for $20 \mathrm{~min}$. Treated and untreated lysates were partitioned into smaller aliquots and heated to different temperatures for $3 \mathrm{~min}$ and then centrifuged to remove precipitated proteins. The supernatant fraction was loaded onto a SDS-PAGE gel and immunoblotted with the indicated antibodies. The red asterisk indicates a background band that cross-reacts with the elF2B4 antibody. Shown is a representative blot $(\mathrm{N}=3)$.

DOI: 10.7554/eLife.07314.013 
GDP $\left(\left[{ }^{3} \mathrm{H}\right]-\mathrm{GDP}\right)$ and measured the fraction that remained bound as a function of time in the presence of an excess of unlabeled GDP. As expected, the intrinsic rate of nucleotide release was slow; after 20 min of incubation, only $20 \%$ of $\left[{ }^{3} \mathrm{H}\right]-$ GDP dissociated from the elF2 complex (Figure $5 \mathrm{~A}$, black dashed line). The intrinsic rate of GDP release was not affected by the addition of ISRIB (Figure 5A, red dashed line). Upon addition of elF2B, we observed a significant increase in the rate of GDP release $\left(\mathrm{t}_{1 / 2}=3.2 \mathrm{~min}\right.$ ), leading to an $80 \%$ release after $10 \mathrm{~min}$ (Figure 5A, solid black line). Excitingly, GDP release was threefold faster upon addition of ISRIB ( $t_{1 / 2}=1.1 \mathrm{~min}$ ) (Figure $5 \mathrm{~A}$, solid red line).

We next tested the behavior of phosphorylated elF2 (elF2-P) in these assays. To this end, we generated elF2-P by incubating elF2 with recombinantly expressed PERK kinase and ATP. We next loaded elF2-P with $\left[{ }^{3} \mathrm{H}\right]-\mathrm{GDP}$ and measured GDP release. As expected from the known inhibitory role of elF2 $\alpha$ phosphorylation on elF2B, GDP release from elF2-P remained virtually unchanged in the presence of eIF2B (Figure $5 B$, black solid line). We next asked whether ISRIB allows elF2-P to be a substrate for elF2B. Our data show that ISRIB did not stimulate GDP release from elF2-P (Figure 5B, red solid line), indicating that this is not the case. We next explored whether ISRIB can overcome the inhibitory effects
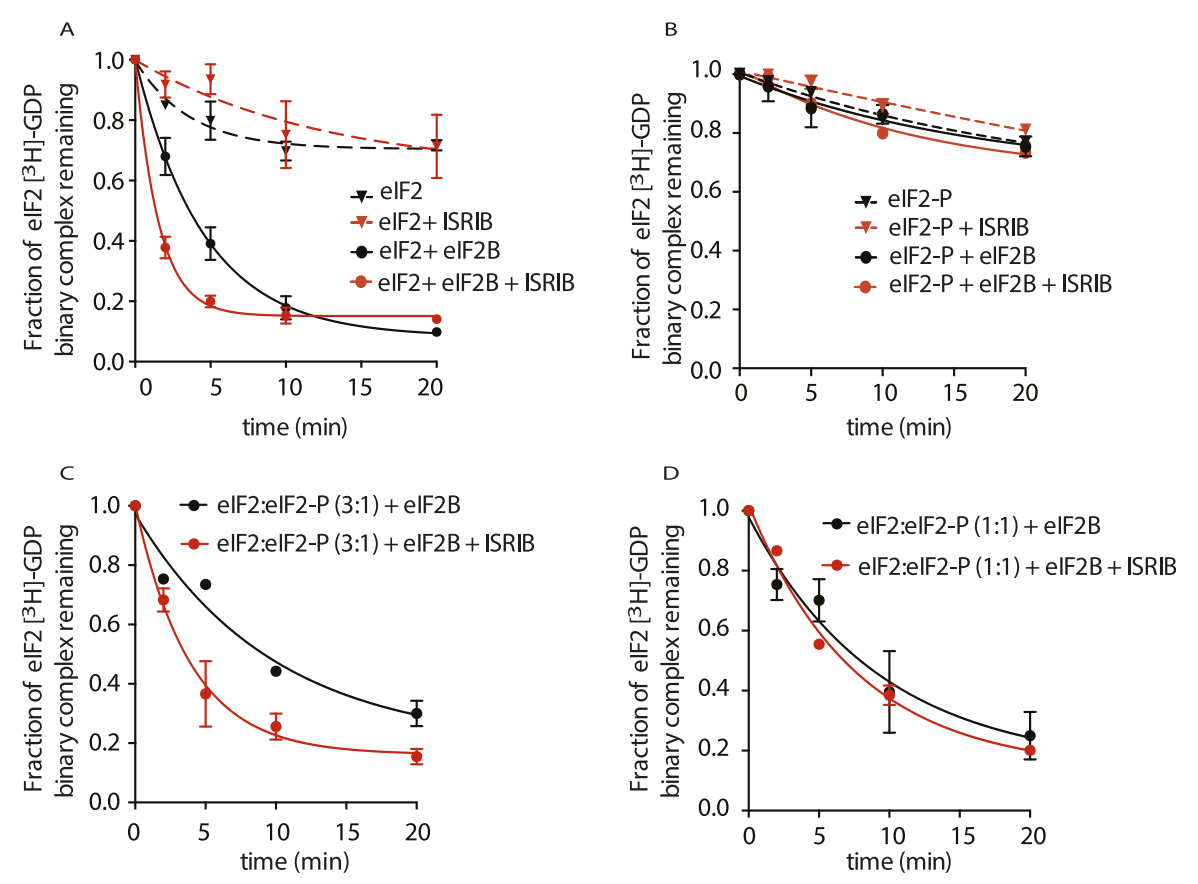

Figure 5. ISRIB enhances the GEF activity of elF2B in vitro. elF2 was preloaded with $\left[{ }^{3} \mathrm{H}\right]-\mathrm{GDP}$ and the fraction of binary complex remaining was measured by filter binding. Partially purified elF2B or buffer was added at $\mathrm{t}=0 \mathrm{~min}$. An aliquot of the reaction was stopped at the indicated times, filtered through a nitrocellulose membrane and radioactivity was measured. (A) Purified elF2 was incubated with buffer ( $\pm 100 \mathrm{nM}$ ISRIB, dashed lines) or partially purified elF2B ( $\pm 100 \mathrm{nM}$ ISRIB, solid lines) for the indicated times and the remaining fraction of [ $\left.{ }^{3} \mathrm{H}\right]-G D P$-elF2 was measured ( $N=3, \pm S D$ ). (B) Purified and phosphorylated elF2 (elF2-P) was preloaded with [ $\left.{ }^{3} \mathrm{H}\right]-\mathrm{GDP}$ and incubated with buffer ( $\pm 100 \mathrm{nM}$ ISRIB, dashed lines) or partially purified elF2B ( $\pm 100 \mathrm{nM}$ ISRIB, solid lines) for the indicated times and the remaining fraction of $\left[{ }^{3} \mathrm{H}\right]$-GDP-elF2 was measured $(\mathrm{N}=2, \pm \mathrm{SD})$. (C) elF2 was preloaded with $\left[{ }^{3} \mathrm{H}\right]$ GDP and mixed with elF2-P at a ratio of 3:1 and then incubated with elF2B with or without $100 \mathrm{nM}$ ISRIB for the indicated times and the remaining fraction of $\left[{ }^{3} \mathrm{H}\right]$-GDP-elF2 was measured $(\mathrm{N}=2, \pm \mathrm{SD})$. (D) elF2 was preloaded with $\left[{ }^{3} \mathrm{H}\right]-$ GDP and mixed with elF2-P at a ratio of $1: 1$ and then incubated with elF2B with or without $100 \mathrm{nM}$ ISRIB for the indicated times and the remaining fraction of $\left[{ }^{3} \mathrm{H}\right]-\mathrm{GDP}-\mathrm{elF} 2$ was measured $(\mathrm{N}=2, \pm \mathrm{SD})$. Purified human elF2 and partially purified rabbit reticulocyte elF2B are shown in Figure 5-figure supplement 1.

DOI: $10.7554 /$ LLife. 07314.014

The following figure supplement is available for figure 5 :

Figure supplement 1. Purified human elF2 (panel $\mathbf{A}$, lane 2), recombinant GST-PERK (panel $\mathbf{A}$, lane 1) and partially purified rabbit reticulocyte eIF2B (panel B) were analyzed by SDS-PAGE and stained with Coomassie blue dye. DOI: 10.7554/eLife.07314.015 
of elF2-P on elF2B. To this end, we tested if ISRIB can promote GDP release from unphosphorylated elF2 in the presence elF2-P by mixing $\left[{ }^{3} \mathrm{H}\right]$-GDP-loaded elF2 with elF2-P in a 3:1 or 1:1 ratio. Although the exchange reaction was slower, ISRIB stimulated GDP release at the elF2:eIF2-P ratio of 3:1 (-ISRIB: $\mathrm{t}_{1 / 2}=6.7 \mathrm{~min}$, vs + ISRIB: $\mathrm{t}_{1 / 2}=2.7 \mathrm{~min}$ ) (Figure $5 \mathrm{C}$ ), whereas we observed hardly any stimulation at the 1:1 ratio (-ISRIB: $\mathrm{t}_{1 / 2}=6.4 \mathrm{~min}$, vs + ISRIB: $\mathrm{t}_{1 / 2}=5.3 \mathrm{~min}$ ) (Figure $5 \mathrm{D}$ ). Thus, the relative ratio of substrate (elF2) to inhibitor (elF2-P) emerges as an important parameter affecting ISRIB's ability to modulate elF2B activity. Taken together, these functional data underscore the notion that ISRIB acts as an activator of eIF2B and that ISRIB alleviates inhibition by elF2-P, as long as eIF2-P is present below threshold levels.

\section{Discussion}

The ISR is controlled by phosphorylation of the general eukaryotic translation initiation factor elF2. Multiple cell signaling pathways converge at a single phosphorylation site on its $\alpha$-subunit where phosphorylation of Ser-51 modulates elF2 $\alpha$ 's interaction with its dedicated, multi-subunit guanine nucleotide-exchange factor (GEF) elF2B. We previously identified and characterized a potent small molecule ISR inhibitor (ISRIB) with good pharmacological properties and showed that it renders cells insensitive to elF2 $\alpha$ phosphorylation upon ISR induction and enhances cognitive function in rodents (Sidrauski et al., 2013). Within a few minutes after administration, ISRIB reverses the effects triggered by elF2 $\alpha$ phosphorylation dissolving RNA stress granules and restoring translation of inhibited mRNAs while reversing de-repression of UORFcontaining mRNAs (Sidrauski et al., 2015). Because ISRIB was identified in a phenotypic cell-based screen, its mechanism of action remained obscure. Here, we report the identification of elF2B as the molecular target of ISRIB. To this end, we used reporter-based shRNA screening, structure-function analyses of ISRIB analogs, biochemical characterization of elF2B oligomerization and thermal stability, and enzymatic analyses of elF2B's GEF activity. The results of our multipronged approach provide a rationale for why ISRIB analogs exhibit twofold symmetry, showed ISRIB-mediated stabilization and activation of elF2B dimers, and suggested elF2B4, also known as its $\delta$-subunit, as a candidate to contain the ISRIB binding site. In the course of this work, we also developed more active ISRIB analogs, improving potency by almost 10 -fold and lowering $\mathrm{EC}_{50}$ values into the high picomolar range in cell culture.

\section{How does ISRIB modulate elF2B?}

In this work, ISRIB emerged as an eIF2B activator. First, ISRIB promoted the formation of or stabilized elF2B dimers ('[elF2B $]_{2}$ ') and enhanced GEF activity in biochemical assays. Second, knockdown of both elF2B4 and elF2B5 subunits rendered cells resistant to the action of ISRIB, presumably because under these conditions the total amount of elF2B that can be activated in cells is reduced. Note that the three other subunits of elF2B were not represented in our focused shRNA library and therefore could not have been identified in the screen. Functioning as an activator, ISRIB joins the still sparsely populated group of unnatural small molecule enzyme activators, while the vast majority of synthetic small molecules that modulate enzyme activity are inhibitors (Wiseman et al., 2010; Zorn and Wells, 2010; Wang et al., 2014). Conversely, knockdown of elF4G1 sensitized cells to ISRIB. This can be explained because, under conditions of reduced elF4G1, overall cap-dependent translation initiation is reduced. A lower concentration of ISRIB could then suffice to generate sufficient amounts of GTP-loaded elF2 to maintain normal rates of translation, even in the presence of elF2 $\alpha-P$. Intriguingly, knockdown of other components of the cap-binding complex, such as elF4A1, or components of the elF3 complex, such as elF3f and elF3b, not only reduced sensitivity to ISRIB but also affected induction of the reporter upon ER stress alone. In agreement with studies in yeast and plants (Szamecz et al., 2008; Roy et al., 2010), knockdown of the elF3 subunits in the library (elF3a, elF3b, and elF3f) reduced translational induction of the reporter, presumably due to elF3's stimulatory effects on re-initiation after translation of short uORFs. Our data therefore provide the first evidence that the mechanism of re-initiation may be similar in mammalian cells.

The differences observed between assorted initiation factors on reporter expression is likely to reflect the extent to which translation initiation was reduced under the different knockdown conditions. Importantly however, only knockdown of the elF2B subunits targeted by shRNAs in the library conferred resistance to ISRIB.

We previously proposed two models that could explain how ISRIB renders cells resistant to the inhibitory effects of elF2 $\alpha-P$ (Sidrauski et al., 2013). First, ISRIB could weaken the effect of elF2 $\alpha-P$ on eIF2B by interfering with its tight and non-productive binding. In this way, more elF2B would be available to reload eIF2 with GTP. Second, ISRIB could enhance the basal activity of elF2B so that the fraction not engaged with elF2 $\alpha-P$ would produce sufficient levels of ternary complex to sustain 
translation in cells. Currently, our in vitro enzymatic data do not allow us to distinguish between these models. While we showed that the rate of GDP release from purified elF2 by eIF2B was significantly enhanced upon addition of ISRIB (and therefore can explain the effect of ISRIB in living cells), we do not know what fraction of our elF2 preparation was isolated in a elF2 $\alpha$ (Ser-51)-phosphorylated state. ISRIB could thus either increase the GEF activity of elF2B on elF2 or diminish the inhibitory effect of a small amount elF2-P present in the assay, akin to the regime that we directly tested by adding increasing amounts of in vitro phosphorylated elF2 to the assay. Our analyses confirmed however that elF2 $\alpha-P$ is not a substrate for elF2B (in agreement with previous reports [Kimball et alo, 1998]), and determined that ISRIB does not enable elF2B to use elF2-P as a substrate.

While catalyzing guanine nucleotide exchange on other GTPases can be effected by relatively simple enzymes, elF2B is a complex molecular machine composed of five different subunits. Much remains uncertain about the structural arrangement of the subunits and how elF2B's activity is regulated (Jennings and Pavitt, 2014). Similarly, how ISRIB exerts its effects on elF2B remains unknown. elF2B subunits are organized into two modules, called the catalytic (elF2B3 and elF2B5) and regulatory (elF2B1, elF2B2 and elF2B4) sub-complexes, containing two and three homologous proteins, respectively. The subunits of the regulatory subcomplex are characterized by highly homologous Rossman folds that bind nucleotides and are adorned by $\mathrm{N}$-terminal extensions of lesser homology between the subunits. Intriguingly, recombinantly expressed elF2B1 purified and crystallized as a stable homodimer, with an extensive buried interface contributed by the nucleotide-binding domains (Bogorad et al., 2014). The residues contributing to the interface are highly conserved among its homologs in the complex. Combined with the SAR analyses indicating ISRIB's obligate twofold symmetry, the discovery that $(\text { elF2B })_{2}$ exist in both yeast and mammalian cells was instrumental in suggesting to us that elF2B is the target of ISRIB (Gordiyenko et al,, 2014; Wortham et al., 2014). According to this model, ISRIB binds to two regulatory elF2B subunits that form part of the interface linking two pentamers.

Native mass spectrometry of mammalian elF2B revealed the existence of stable subcomplexes that lack the elF2B1 subunit, indicating that this subunit is more loosely associated, as we confirmed here by sedimentation of the non-ISRIB treated control extracts (Wortham et alo, 2014). We have shown by biochemical analysis that ISRIB binding stabilizes (eIF2B) ${ }_{2}$, rendering it resistant to dissociation of elF2B1 in the high-salt buffers used in the sucrose gradient analysis. Importantly, we showed by mass spectrometric proteomic analysis that no other protein co-profiled with (elF2B) ${ }_{2}$ in the gradients, demonstrating that the observed ISRIB-dependent effects were confined exclusively to elF2B subunits.

Given the relative stability of the elF2B1 homodimer $\left(K_{d}<1 \mathrm{nM}\right.$; [Bogorad et al., 2014]) and our observation that ISRIB stabilized complete (elF2B) 2 , it is likely that two opposing elF2B1 subunits form an essential part of the interface that links two elF2B pentamers. ISRIB could favor this interaction by adding to the affinity provided by a (elF2B1 $)_{2}$ tether via the stabilization of an additional interface formed between homologous regions of two elF2B4 subunits. This view would be in agreement with our data that showed protection by ISRIB of elF2B4 to thermal denaturation. For symmetry reasons, as elegantly discussed in (Bogorad et alo, 2014), this arrangement would leave the interfaces of the two identical elF2B2 subunits in the complex unpaired. Alternatively, ISRIB may stabilize interfaces between elF2B4 in one elF2B pentamer and elF2B2 in an opposing pentamer. If this were the case, ISRIB would bind at a pseudo-symmetric interface formed by two different, yet strongly homologous components. We note in this scenario, two ISRIB molecules binding to two identical interfaces of opposite polarity (eIF2B2 $\rightarrow$ elF2B4 and elF2B4 $\rightarrow$ elF2B2) may bind and stabilize one (elF2B) ${ }_{2}$, which may contribute to its potency. This would open the possibility that design and synthesis of nonsymmetric analogs could further improve ISRIB's efficacy. A definite assignment of ISRIB's binding site will have to await the structural determination of ISRIB-bound (elF2B) $)_{2}$ or genetic analyses in which loss-of-function mutations are suppressed by compensating changes in ISRIB analogs.

Consistent with the notion that the regulatory sub-complex provides binding sites for elF2, mutations in elF2B in yeast that render cells resistant to phosphorylation of elF2 $\alpha$ map to elF2B1 and elF2B4 (Pavitt et al., 1997). Moreover, two different variants in mammalian elF2B4 (generated by alternative splicing) contain different $\mathrm{N}$-terminal extension domains and exclusive expression of the longer variant desensitizes cells to elF2 $\alpha$ phosphorylation (Martin et al., 2010), phenocopying the effects elicited by ISRIB in mammalian cells. In the structure of (elF2B1) 2 the $\mathrm{N}$-terminal domains reach across the interface and interact with the nucleotide binding domain of the partnering elF2B1 molecule. We speculate that the extended $\mathrm{N}$-terminal domain of elF2B4 may stabilize (elF2B) mimicking the effects of ISRIB. 


\section{Importance of elF2-mediated translational control in disease}

Phosphorylation of elF2 is important in long-term depression (LTD), and we have recently shown that this modulation of synaptic plasticity can explain cognitive enhancement elicited by ISRIB treatment of wild type rodents (Di Prisco et al., 2014). Engagement of metabotropic glutamate receptors (mGluR) in post-synaptic hippocampal cells leads to elF2 phosphorylation and preferential translation of neuronally expressed oligophrenin-1 (encoded by OPHN1), a protein that mediates the initial steps of downregulation of postsynaptic AMPA receptors by endocytosis (Nadif Kasri et al., 2011). Like ATF4, the 5'-UTR of OPHN1 mRNA contains two UORFs that repress expression of the downstream coding sequence unless elF2 is phosphorylated. Importantly, both genetic ablation of elF2 phosphorylation and treatment with ISRIB but not the inactive analog ISRIB-A18 abolished the reduction in surface AMPARs and blocked mGluR-LTD (Di Prisco et al., 2014). These findings hold promise that targeting the effects of phosphorylation of elF2 by pharmacologically modulating elF2B with drugs such as ISRIB could result in therapies for cognitive disorders. Activation of the ISR with its characteristic increase in elF2 phosphorylation has been reported in numerous neurodegenerative diseases, including Alzheimer's disease, Parkinson's disease, Frontotemporal Dementia, Amyotrophic Lateral Sclerosis, and prion neurodegenerative diseases, but its role in disease progression has just recently begun to be interrogated (Kim et al., 2013; Leitman et al., 2014; Ma et al., 2013; Moreno et al., 2013, 2012).

The importance of elF2 and elF2B in brain function is underscored by the existence of mutations in these factors that cause human disease. A familial intellectual disability syndrome was mapped to a mutation in the $\gamma$ subunit of elF2 (encoded by EIF2S3). When an analogous mutation was introduced into yeast cells, it impaired elF2-mediated translation initiation (Borck et al., 2012). Mutations in the different subunits of elF2B cause childhood ataxia with central nervous system (CNS) hypomyelination ( $\mathrm{CACH}$ ) or vanishing white matter disease (VWMD). All affected individuals have two altered copies of a single elF2B gene (autosomal recessive inheritance) and the majority are missense mutations that cause a single amino acid change while the remainder is a mixture of premature nonsense mutations, some causing a frame-shift and others altered splicing. All subunits of elF2B are essential and the biochemical analysis of 40 different VWMD mutations revealed that the majority are hypomorphs, that is, cause partial loss-of function of elF2B GEF activity (Leegwater et al., 2001; Li et al., 2004; Fogli and Boespflug-Tanguy, 2006). Whether ISRIB can reverse the deleterious effects of mutations in elF2B in VWMD patients is not known, but we speculate that it may protect from a further reduction in GEF activity by stress-induced elF $2 \alpha-P$. Intriguingly, the onset of VWMD is varied but generally exacerbated by head trauma and febrile illnesses. Interestingly, two VWMD mutations have been characterized that affect the integrity and dimerization of the elF2B complex. A mutation in elF2B1(V183F) maps to the dimerization interface and the mutant recombinant protein is predominantly in the monomeric form and a mutation in elF2B4(A391D) affects complex integrity in the absence of elF2B1 and dimerization (Wortham et al., 2014). ISRIB induces dimerization and complex stability and thus may rescue the effects of such mutations.

Given the wide spectrum of potential applications for ISRIB in neurological diseases, the identification of its molecular target is an important step. Having established a proof-of-principle that elF2B can be pharmacologically modulated, now enables directed screening efforts to identify new series of compounds and thereby enhance the probability of developing clinically useful pharmaceuticals that address currently unmet needs.

\section{Note added at proof}

While this work was under review, Sekine et al. reported the independent identification of elF2B as the molecular target of ISRIB (Sekine et al., 2015).

\section{Materials and methods}

\section{Chemicals}

Thapsigargin (Tg) was obtained from Sigma-Aldrich (St Louis, MO). Tunicamycin (Tm) was obtained from Calbiochem EMB Bioscience (Billerica, CA). The GSK PERK inhibitor (G797800) was obtained from Toronto Research Chemicals (North York, ON, Canada). 


\section{Cell culture}

HEK293T and K562 cells were maintained at 37C, 5\% CO 2 in either DMEM (HEK293T) or RPMI (K562) media supplemented with 10\% FBS, L-glutamine and antibiotics (penicillin and streptomycin).

\section{shRNA screening reporter cell line}

The lentiviral reporter vector, pMK1163, contains a CMV promoter driving expression of a fusion transcript with the following elements: the $5^{\prime}$ end of the human ATF4 mRNA up to the start codon of the ATF4-encoding ORF, an ORF encoding Venus (adapting a previously published strategy [ Lu et al., 2004; Vattem and Wek, 2004]), followed by an IRES driving translation of tagBFP. The elements of this vector were generated as follows: we PCR-amplified the ATF4 region from human cDNA prepared from $\mathrm{K} 562$ cells using primers oMK305 (5'-CGTACTCGAGTTTCTACTTTGCCCGCCCA CAG-3') and oMK306 (5'-GCTCCTCGCCCTTGCTCACCATGTTGCGGTGCTTTGCTGGAATCG-3'). Venus was amplified from DAA307 (gift from Diego Acosta-Alvear), using primers oMK272 (5'-ATGGTGAGCAAGGGCGAGGAGC-3') and oMK308 (5'-GCTAGAATTCTTACTTGTACAGCTCGTC CATGCC-3'). The ATF4-Venus fusion was generated by PCR reaction using the two PCR products described above as templates, and oMK305 and oMK308 as primers. The EMCV IRES was amplified from plasmid pPPCX-IRES-GFP (gift from Diego Acosta-Alvear). tagBFP was amplified from a tagBFP plasmid (Evrogen, Moscow, Russia). The plasmid pMK1163 is in the lentiviral vector pSicoR (Ventura et al., 2004), and its sequence is provided in Figure 1-source data 1. Human K562 cells were transduced with pMK1163 and monoclonal cell lines were generated using FACS. One clone was selected as our reporter cell line based on low base-line expression of Venus and high expression following thapsigargin treatment (high dynamic range).

\section{Pooled shRNA screen}

The reporter cell line was transduced with a pooled next-generation shRNA library. We used a sublibrary that targets 2933 human genes associated with proteostasis, each with on average 25 independent shRNAs, and contains $>1000$ negative control shRNAs. After transduction, transduced cells were selected with puromycin $(0.65 \mu \mathrm{g} / \mathrm{ml})$ for 2 days, and then grown in the absence of puromycin for 2 days. Cells were then separated into two populations, which were treated for $7 \mathrm{hr}$ with either $300 \mathrm{nM}$ thapsigargin alone or $300 \mathrm{nM}$ thapsigargin and $15 \mathrm{nM}$ ISRIB. Cells were then sorted based on reporter fluorescence using a BD FACS Aria2. Cells from the thirds of the population with the highest and lowest reporter levels were collected. Genomic DNA was isolated from FACSsorted populations, and shRNA-encoding cassettes were PCR-amplified and subjected to deep sequencing as previously described (Kampmann et al., 2014). Using our previously described analysis pipeline (Kampmann et al., 2013, 2014), we calculated a quantitative phenotype $\varepsilon$ for each shRNA, which represents the $\log _{2}$ ratio of its frequency in the high-fluorescence population over its frequency in the low-fluorescence population, from which the median of the negative control phenotypes was subtracted (Kampmann et al., 2013). For each gene, $\varepsilon$ phenotypes for the $\sim 25$ shRNAs targeting the gene were compared to $\varepsilon$ phenotypes for the negative control shRNAs, and $p$ values were calculated using the Mann-Whitney $U$ test to detect genes whose knockdown significantly modulated activation of the uORFs-ATF4-venus reporter in response to thapsigargin in the absence or presence of ISRIB. $p$ values for all 2933 genes targeted by the sublibrary we used are listed in Figure 1-source data 2.

\section{Cell-based assay to measure the potency of ISRIB analogs}

HEK293T cells carrying an ATF4 luciferase reporter (as previously described in [Sidrauski et al., 2013]) were plated on poly-lysine coated 96 well plates (Greiner Bio-One, Monroe, NC) at 30,000 cells per well. Cells were treated the next day with tunicamycin $(1 \mu \mathrm{g} / \mathrm{ml})$ and different concentrations (serial dilution) of each compound for $7 \mathrm{hr}$. Luminescence was measured using One Glo (Promega, Madison, $\mathrm{WI})$ as specified by the manufacturer. $\mathrm{EC}_{50}$ values were calculated by plotting $\log _{10}[\mu \mathrm{M}]$ for each compound as a function of the relative luminescence intensity or response. The $\mathrm{EC}_{50}$ corresponds to the concentration that provokes a half-maximal response.

\section{Sucrose gradients}

HEK293T cells were plated on $150 \mathrm{~mm}$ plates, treated with or without $200 \mathrm{nM}$ ISRIB for $20 \mathrm{~min}$, washed twice with ice-cold PBS, collected and centrifuged for $3 \mathrm{~min}$ at $800 \mathrm{rcf}$ at $4^{\circ} \mathrm{C}$. The pellets were 
resuspended in ice-cold lysis buffer: $50 \mathrm{mM}$ Tris $\mathrm{pH}=7.5,400 \mathrm{mM} \mathrm{KCl}, 4 \mathrm{mM} \mathrm{Mg}(\mathrm{OAc})_{2}, 0.5 \%$ Triton $\mathrm{X}-100$ and protease inhibitors (EDTA-free protease inhibitor tablets, Roche, South San Francisco, CA). The lysates were clarified at $20,000 \times \mathrm{g}$ for $15 \mathrm{~min}$ at $4^{\circ} \mathrm{C}$ and the supernatant was then subjected to a high-speed spin at $100,000 \times g$ for $30 \mathrm{~min}$ at $4^{\circ} \mathrm{C}$ to pellet the ribosomes. The supernatants were then loaded on a 5-20\% sucrose gradient and centrifuged in a SW55 rotor for $14 \mathrm{hr}$ at 40,000 rpm $4^{\circ} \mathrm{C} .13$ fractions were collected, protein was chloroform-methanol precipitated, resuspended in SDS-PAGE loading buffer and loaded on SDS-PAGE 10\% gels (Bio-Rad, Hercules, CA).

\section{Protein analysis}

Proteins were transferred to nitrocellulose and probed with primary antibodies diluted in phosphatebuffered saline supplemented with $0.1 \%$ Tween 20 and $5 \%$ bovine serum albumin. The following antibodies were used: elF2B1 (1:1000; Proteintech 18010-1-AP, Chicago, IL), elF2B2 (1:500; Proteintech 11034-1-AP), elF2B4 (1:1000; Proteintech 11332-1-AP), elF2B5 (1:500; Santa Cruz Biotechnologies sc-5558, Dallas, TX), elF3a (1:1500; Cell Signaling Technology \#3411, Danvers, MA) and elF2 $\alpha$ (1: 1500; Cell Signaling Technology \#5324). Following primary antibody incubation, either HRPconjugated secondary antibody (Promega) or IRdye conjugated secondary antibodies (LI-COR Biosciences, Lincoln, NE) was used. Immunoreactive bands were detected using either enhanced chemi-luminescence (Bio-Rad) or the LI-COR Odyssey imaging system.

\section{Mass spectrometry of sucrose gradient fractions}

HEK293T cells were treated with ISRIB or ISRIB ${ }^{\text {inact }}$ (ISRIB-A18, Figure 3-figure supplement 1) at 200 $\mathrm{nM}$ for $20 \mathrm{~min}$. Cells were then subjected to three liquid nitrogen freeze-thaw cycles in a modified lysis buffer devoid of Triton X-100 and supplemented with ISRIB or ISRIB ${ }^{\text {inact }}$ at $50 \mathrm{nM}$. Lysates were loaded onto a 5-20\% sucrose gradient. Proteins in fractions 6-9 were chloroform-methanol precipitated and re-suspended in $0.1 \mathrm{M}$ tetraethylammonium bromide (TEAB), $150 \mathrm{mM} \mathrm{NaCl}$ and $8 \mathrm{M}$ Urea and digested with trypsin as previously described (Ramage et al., 2015).

Digested peptide mixtures were analyzed in technical duplicate by LC-MS/MS on a Thermo Scientific LTQ Orbitrap Elite mass spectrometry system equipped with a Proxeon Easy nLC 1000 ultra high-pressure liquid chromatography and autosampler system. Samples were injected onto a C18 column (25 cm × $75 \mu \mathrm{m}$ I.D.) packed with ReproSil Pur C18 AQ (1.9 $\mu \mathrm{m}$ particles) in $0.1 \%$ formic acid and then separated with a 1-hr gradient from $5 \%$ to $30 \%$ ACN in $0.1 \%$ formic acid at a flow rate of 300 $\mathrm{nl} / \mathrm{min}$. The mass spectrometer collected data in a data-dependent fashion, collecting one full scan in the Orbitrap at 120,000 resolution followed by 20 collision-induced dissociation MS/MS scans in the dual linear ion trap for the 20 most intense peaks from the full scan. Dynamic exclusion was enabled for $30 \mathrm{~s}$ with a repeat count of one. Charge state screening was employed to reject analysis of singly charged species or species for which a charge could not be assigned.

Raw mass spectrometry data were analyzed using the MaxQuant software package (version 1.3.0.5) (Cox and Mann, 2008). Data were matched to the SwissProt human proteins (downloaded from UniProt on 2/15/13, 20,259 protein sequence entries). MaxQuant was configured to generate and search against a reverse sequence database for false discovery rate calculations. Variable modifications were allowed for methionine oxidation and protein $\mathrm{N}$-terminus acetylation. A fixed modification was indicated for cysteine carbamidomethylation. Full trypsin specificity was required. The first search was performed with a mass accuracy of \pm 20 parts per million and the main search was performed with a mass accuracy of \pm 6 parts per million. A maximum of five modifications were allowed per peptide. A maximum of two missed cleavages were allowed. The maximum charge allowed was 7+. Individual peptide mass tolerances were allowed. For MS/MS matching, a mass tolerance of $0.5 \mathrm{Da}$ was allowed and the top six peaks per $100 \mathrm{Da}$ were analyzed. MS/MS matching was allowed for higher charge states, water and ammonia loss events. The data were filtered to obtain a peptide, protein, and site-level false discovery rate of 0.01 . The minimum peptide length was 7 amino acids. Results were matched between runs with a time window of 2 min for technical duplicates.

\section{CETSA}

CETSA were adapted from a previously described protocol (Martinez Molina et al., 2013). HEK293T cells were lysed in a buffer containing: $50 \mathrm{mM}$ Tris $\mathrm{pH}=7.5,400 \mathrm{mM} \mathrm{KCl}, 4 \mathrm{mM} \mathrm{Mg}(\mathrm{OAc})_{2}$, $0.5 \%$ Triton X-100 and protease inhibitors (EDTA-free protease inhibitor tablets, Roche). The lysates 
were clarified at $20,000 \times \mathrm{g}$ for $15 \mathrm{~min}$ at $4^{\circ} \mathrm{C}$. The supernatant was then incubated with ISRIB $(1 \mu \mathrm{M}$, $0.1 \% \mathrm{DMSO})$ or DMSO $(0.1 \%)$ at $30^{\circ} \mathrm{C}$ for $20 \mathrm{~min}$, and subsequently spun at $100,000 \times \mathrm{g}$ for $30 \mathrm{~min}$ at $4^{\circ} \mathrm{C}$ to pellet ribosomes. Supernatants following the high-speed spin were divided into PCR tubes and subjected to a gradient of temperatures for $3 \mathrm{~min}$ using the thermal cycler's built-in gradient function, such that column one corresponded to $52^{\circ} \mathrm{C}$ and column 12 corresponded to $62^{\circ} \mathrm{C}$ (Tetrad 2 Thermal Cycler, Bio-Rad). Samples were allowed to cool for $3 \mathrm{~min}$ at room temperature, transferred to microfuge tubes, and spun at $20,000 \times g$ for $20 \mathrm{~min}$ at $4^{\circ} \mathrm{C}$ to separate the soluble fraction from the insoluble precipitates. The soluble fraction was then loaded on a 10\% SDS-PAGE gel (Bio-Rad) and analyzed by Western blotting as described above.

\section{Purification of elF2B}

Rabbit reticulocyte lysate was obtained from Greenhectares (http://greenhectares.com). elF2B was purified as previously described (Oldfield and Proud, 1992). In brief, the reticulocyte lysate was thawed and protease inhibitor added (EDTA-free protease inhibitor tablets, Roche). Ribosomes were precipitated by centrifugation $\left(45,000 \mathrm{rpm}\right.$ for $4.5 \mathrm{hr}$, Beckman $50.2 \mathrm{Ti}$ at $\left.4^{\circ} \mathrm{C}\right)$ and the supernatant was used as a source of elF2B. $\mathrm{KCl}$ was added slowly to $100 \mathrm{mM}$ final concentration and filtered using a $0.2 \mu \mathrm{M}$ conical tube filter unit. The filtrate was loaded on a SPSepharose fast flow column $(20 \mathrm{ml})$ pre-equilibrated with Buffer $\mathrm{A}(20 \mathrm{mM}$ Hepes/ $\mathrm{NaOH} \mathrm{pH}=7.6$, $10 \%$ glycerol, $100 \mathrm{mM} \mathrm{KCl}, 0.1 \mathrm{mM}$ EDTA and $2 \mathrm{mM} \mathrm{DTT})$. A step gradient was used (100, 200 and $400 \mathrm{mM} \mathrm{KCl}$ ). elF2B eluted at $400 \mathrm{mM} \mathrm{KCl}$. The eluate was diluted slowly by adding Buffer A (with no $\mathrm{KCl}$ ) to $100 \mathrm{mM} \mathrm{KCl}$ and then loaded on a Q-Sepharose $(20 \mathrm{ml})$ pre-equilibrated with Buffer $A$. A step gradient was used $(300 \mathrm{mM}$ and $500 \mathrm{mM} \mathrm{KCl}$ ) with elF2B eluting at $500 \mathrm{mM} \mathrm{KCl}$. The eluate was dialyzed overnight with Buffer $A$ and loaded to a Mono $Q$ (5-50 GL, GE Healthcare, Wauwatosa, WI) equilibrated with buffer A (a continuous gradient 100-500 $\mathrm{mM} \mathrm{KCl}$ was used) and elF2B eluted at $350 \mathrm{mM} \mathrm{KCl}$. The eluate was buffer exchanged with Buffer $A$ and aliquots were flash frozen in liquid $\mathrm{N}_{2}$.

\section{Purification of elF2}

Human elF2 was purified from HeLa cells as described previously (Fraser et al., 2007). In brief, from the 40-50\% ammonium sulfate precipitate of post-nuclear HeLa cell lysate, elF2 was purified through a series of chromatographic steps which included a Mono Q 10/10 column (GE Healthcare), a Mono S 10/10 column (GE Healthcare), a CHT5-1 ceramic hydroxyapatite column (Bio-Rad), and a Superose 6 $16 / 60$ column (GE Healthcare). The protein was stored at $-80^{\circ} \mathrm{C}$ in buffer containing $20 \mathrm{mM}$ Hepes- $\mathrm{K}$ $\mathrm{pH} 7.5,150 \mathrm{mM} \mathrm{KCl}, 1 \mathrm{mM}$ DTT, and 10\% glycerol.

\section{GDP dissociation assay}

GDP dissociation assays were adapted from a previously described protocol (Sokabe et al., 2012). For each reaction purified elF2 (21 pmol) was incubated with $0.6 \mu \mathrm{Ci}\left[{ }^{3} \mathrm{H}\right.$ ]-GDP $(40 \mathrm{Ci} /$ mmol, PerkinElmer, Waltham, MA) in a reaction buffer $(20 \mathrm{mM} \mathrm{HEPES} \mathrm{pH} \mathrm{7.5,80} \mathrm{mM} \mathrm{KCl,} 1 \mathrm{mM}$ DTT, $1 \mathrm{mg} / \mathrm{ml}$ creatine phosphokinase (EMD Millipore, Billerica, MA), 5\% glycerol) without magnesium at $37^{\circ} \mathrm{C}$ for $10 \mathrm{~min}$, and then further incubated with $1 \mathrm{mM} \mathrm{Mg}(\mathrm{OAc})_{2}$ at $30^{\circ} \mathrm{C}$ for $3 \mathrm{~min}$ with or without ISRIB $(100 \mathrm{nM})$ in a total volume of $60 \mu \mathrm{l}$. The reaction was initiatied by the addition of $60 \mathrm{nmol}$ unlabeled GDP with or without elF2B $(0.6 \mu$ l of partially purified rabbit reticulocyte elF2B, which correspond to approximately 0.3 pmoles of the complex). At each time point, an aliquot was taken $(10 \mu \mathrm{l})$ and the reaction was stopped by addition to $300 \mu \mathrm{l}$ ice-cold stop buffer (reaction buffer with $5 \mathrm{mM} \mathrm{Mg}(\mathrm{OAc})_{2}$ ), immediately filtered through a HAWP nitrocellulose membrane filter (EMD Millipore) on a vacuum manifold, and washed twice with $1 \mathrm{ml}$ icecold stop buffer. Filters were dried and remaining $\left[{ }^{3} \mathrm{H}\right]-\mathrm{GDP}$ bound to elF2 was counted by liquid scintillation in Ecoscint (National Diagnostics, Atlanta, GA). Data collected were fitted to a first-order exponential decay.

elF2-P was synthesized by incubating elF2 $(1.76 \mu \mathrm{M})$ with recombinant GST-PERK $(500 \mathrm{nM})$ at $37^{\circ} \mathrm{C}$ for $45 \mathrm{~min}$ in a reaction buffer containing: $0.5 \mathrm{mM} \mathrm{ATP}, 50 \mathrm{mM}$ Tris- $\mathrm{HCl} \mathrm{pH} \mathrm{7.5,4} \mathrm{mM} \mathrm{MgCl}, 100 \mathrm{mM}$ $\mathrm{NaCl}, 1 \mathrm{mM}$ tris(2-carboxyethyl)phosphine (TCEP), 1\% glycerol. The phosphorylation reaction was stopped by the addition of $1 \mu \mathrm{M}$ GSK PERK inhibitor (Toronto Research Chemicals) and 4 mM EDTA to chelate magnesium ions. For elF2-P•GDP dissociation reactions (Figure 5B), elF2-P (21 pmol) was loaded with $\left[{ }^{3} \mathrm{H}\right]$-GDP. For experiments where elF2 was mixed with elF2-P (Figure $5 C, D$ ), 
unphosphorylated elF2 was loaded with $\left[{ }^{3} \mathrm{H}\right]$-GDP and mixed (3:1 or 1:1) with elF2-P, which was not loaded with $\left[{ }^{3} \mathrm{H}\right]-$ GDP, such that the sum of elF2 and elF2-P equaled 21 pmol. GDP dissociation assays were conducted as described above in the presence of $50 \mathrm{nM}$ GSK PERK inhibitor to ensure that the residual PERK kinase did not phosphorylate elF2 during the course of the dissociation assay.

\section{Purification of GST-PERK}

Cytosolic human PERK was codon-optimized for Escherichia coli expression by Genewiz Inc. A construct was then cloned into a PGEX-6P-2 vector for expression using two rounds of In-Fusion cloning (Clontech, Mountain View, CA) (535-1093 $\Delta 660-868)$. The cytosolic portion of PERK, lacking the unstructured loop region (amino acids 535-1093 $\Delta 660-868$ ) was then co-expressed with a tag-less lambda phosphatase to produce a fully dephosphorylated PERK protein in BL21 star (DE3) (Life Technologies, Carlsbad, CA). Cells were grown to an $\mathrm{OD}_{600}$ of 0.5 before induction with $0.1 \mathrm{mM}$ IPTG at $15^{\circ} \mathrm{C}$ for $24 \mathrm{hr}$. Cells where harvested and lysed using AVESTIN Emulsiflex-C3 in a buffer containing $50 \mathrm{mM}$ Tris- $\mathrm{HCl}$, pH 8.0, $500 \mathrm{mM} \mathrm{NaCl}, 5 \%$ glycerol, $5 \mathrm{mM}$ TCEP (buffer A) and EDTA-free COMPlete protease inhibitor cocktail (Roche). The lysate was cleared by centrifugation at $100,000 \times g$ before batch-binding to a GST-Sepharose resin. The resin was washed 5 times with buffer $A$. The protein was loaded onto a HiTrap Q HP column to remove remaining lambda phosphatase. The PERK (535-1093 $\Delta 660-868$ ) protein was then concentrated and fractionated on a Superdex $200 \mathrm{GL}$ (GE Healthcare) to remove protein aggregates.

\section{Chemical syntheses}

General methods

Commercially available reagents and solvents were used as received. Compounds ISRIB-A1 and ISRIB-A2 were prepared as previously reported (Sidrauski et al., 2013b). Compound ISRIB-A7 was available commercially from Specs (The Netherlands). ${ }^{1} \mathrm{H}$ NMR spectra were recorded on a Varian INOVA-400 $400 \mathrm{MHz}$ spectrometer and a Bruker Avance $300300 \mathrm{MHz}$ spectrometer. Chemical shifts are reported in $\delta$ units (ppm) relative to residual solvent peak. Coupling constants $(J)$ are reported in hertz $(\mathrm{Hz})$. LC-MS analyses were carried out using Waters 2795 separations module equipped with Waters 2996 photodiode array detector, Waters 2424 ELS detector, Waters micromass ZQ single quadropole mass detector, and an XBridge C18 column (5 $\mu \mathrm{m}, 4.6 \times 50 \mathrm{~mm})$. Microwave reactions were carried out in a CEM Discover microwave reactor.

\section{General procedure A for amide coupling}

To a solution of the carboxylic acid (1 equiv.) in N,N-dimethylformamide, were sequentially added 1-hydroxybenzotriazole hydrate (1.2 equiv.), 1-(3-dimethylaminopropyl)-3-ethylcarbodiimide hydrochloride (1.2 equiv.), 2-(4-chlorophenoxy)- $\mathrm{N}-[(1 \mathrm{r}, 4 \mathrm{r})$-4-aminocyclohexyl]acetamide trifluoroacetic acid (1.0 equiv., prepared as described in the synthesis of ISRIB-A8, below) and N,Ndiisopropylethylamine (1.5 equiv). The reaction mixture was stirred at room temperature until judged complete by LC-MS and then diluted with water $(2 \mathrm{ml})$. The mixture was vigorously vortexed, centrifuged and the water was decanted. This washing protocol was repeated with water ( $2 \mathrm{ml})$ and then with diethyl ether $(2 \mathrm{ml})$. The wet solid was dissolved in dichloromethane $(10 \mathrm{ml})$ and dried over anhydrous magnesium sulfate. The solids were removed by filtration and the filtrate was concentrated by rotary evaporation to obtain the product.

\section{General procedure B for amide coupling}

To a solution of the carboxylic acid (2 equiv.) in N,N-dimethylformamide were sequentially added 1hydroxybenzotriazole hydrate (2 equiv.), 1-(3-dimethylaminopropyl)-3-ethylcarbodiimide hydrochloride (2 equiv.), the diamine (1.0 equiv.) and $\mathrm{N}, \mathrm{N}$-diisopropylethylamine (6 equiv). The reaction mixture was stirred at room temperature until judged complete by LC-MS and then diluted with water. The precipitate formed was washed with water and $10 \%$ diethyl ether in dichloromethane. The precipitate was dried in vacuo to obtain the product.

\section{General procedure $\mathbf{C}$ for amide coupling}

To a solution of $(1 r, 4 r)$-cyclohexane-1,4-diamine (1 equiv.) in $\mathrm{N}, \mathrm{N}$-dimethylformamide were added the carboxylic acid (2 equiv.), 1-[bis(dimethylamino)methylene]-1H-1,2,3-triazolo[4,5-b]pyridinium 3-oxid 
hexafluorophosphate (2.1 equiv.) and N,N-diisopropylethylamine (4 equiv.). The reaction mixture was vigorously stirred at room temperature until judged complete by LC-MS. Water (2 $\mathrm{ml})$ was added. The mixture was centrifuged and the water was decanted. This washing protocol was repeated thrice and the resulting wet solid was concentrated down with toluene $(10 \mathrm{ml})$ in a rotary evaporator. The residual product was washed with diethyl ether $(10 \mathrm{ml})$ and concentrated using rotary evaporation to obtain the product.

\section{2-(4-Chlorophenoxy)-N-\{4-[2-(4-chlorophenoxy)acetamido]butyl\} acetamide (ISRIB-A3)}<smiles>O=C(COc1ccc(Cl)cc1)NCCCCNC(=O)COc1ccc(Cl)cc1</smiles>

To a solution of 1,4-diaminobutane $(0.032 \mathrm{~g}, 0.2 \mathrm{mmol})$ in tetrahydrofuran $(1.0 \mathrm{ml})$, were added 4-chlorophenoxyacetyl chloride $(0.062 \mathrm{ml}, 0.4 \mathrm{mmol})$ and $\mathrm{N}, \mathrm{N}$-diisopropylethylamine $(0.173 \mathrm{ml}, 1.0$ $\mathrm{mmol})$. The reaction mixture was stirred at room temperature for $20 \mathrm{hr}$ and then partitioned between 1:1 mixture of water/dichloromethane $(20 \mathrm{ml})$. The organic layer was washed with $10 \%$ aqueous potassium hydrogen sulfate, water and brine. The organic phase was then dried over magnesium sulfate, filtered, and concentrated to obtain a brownish orange solid. The brownish orange solid was triturated with diethyl ether and the resulting solids were separated by centrifugation and dried to obtain $26 \mathrm{mg}$ (31\%) of the title compound as tan powder. ${ }^{1} \mathrm{H}$ NMR $(400 \mathrm{MHz}, \mathrm{DMSO}-\mathrm{d} 6) \delta 8.06(\mathrm{t}, \mathrm{J}=$ $5.6 \mathrm{~Hz}, 2 \mathrm{H}), 7.30-7.32 \mathrm{~m}, 4 \mathrm{H}), 6.93-6.95(\mathrm{~m}, 4 \mathrm{H}), 4.43(\mathrm{~s}, 4 \mathrm{H}), 3.08(\mathrm{~d}, \mathrm{~J}=5.7 \mathrm{~Hz}, 4 \mathrm{H}), 1.37(\mathrm{br} . \mathrm{s}, 4 \mathrm{H})$ LC-MS: $\mathrm{m} / \mathrm{z}=425[\mathrm{M}+\mathrm{H}, 35 \mathrm{Cl}]+, 427[\mathrm{M}+\mathrm{H}, 37 \mathrm{Cl}]+$.

\section{2-(4-Chlorophenoxy)-N-[(1r,3r)-3-[2-(4-chlorophenoxy)acetamido] cyclobutyl]acetamide (ISRIB-A4)}

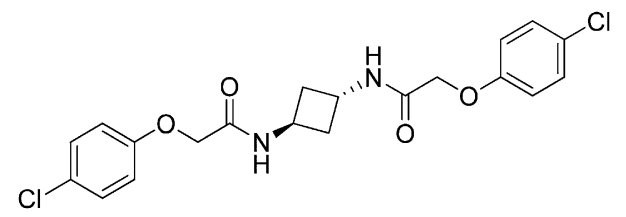

To a cooled $\left(0^{\circ} \mathrm{C}\right)$ solution of tert-butyl $\mathrm{N}$-[(1r,3r)-3-aminocyclobutyl]carbamate $(0.05 \mathrm{~g}, 0.277 \mathrm{mmol})$ in 1,2-dichloroethane $(1.38 \mathrm{ml})$, was added trifluoroacetic acid $(1.38 \mathrm{ml})$. The reaction mixture was stirred at room temperature for $2 \mathrm{hr}$ and then concentrated down to dryness to obtain $100 \mathrm{mg}$ of $(1 \mathrm{r}, 3 \mathrm{r})$ cyclobutane-1,3-bis(aminium) ditrifluoroacetate which was used without further purification.

To a solution 4-chlorophenoxyacetic acid $(0.19 \mathrm{~g}, 0.63 \mathrm{mmol})$ in $\mathrm{N}, \mathrm{N}$-dimethylformamide $(1.0 \mathrm{ml})$ were sequentially added 1-hydroxybenzotriazole hydrate $(0.12 \mathrm{~g}, 0.63 \mathrm{mmol})$, 1-(3dimethylaminopropyl)-3-ethylcarbodiimide hydrochloride $(0.175 \mathrm{~g}, 0.63 \mathrm{mmol}),(1 \mathrm{r}, 3 \mathrm{r})$-cyclobutane1,3-bis(aminium) ditrifluoroacetate $(0.1 \mathrm{~g}, 0.31 \mathrm{mmol})$ and $\mathrm{N}, \mathrm{N}$-diisopropylethylamine $(0.34 \mathrm{ml}, 1.91$ $\mathrm{mmol})$. The reaction mixture was stirred at room temperature for $2 \mathrm{hr}$ and then subjected to conditions described in procedure $B$ to afford $72 \mathrm{mg} \mathrm{(54 \% )}$ of the title compound. ${ }^{1} \mathrm{H} \mathrm{NMR}(300 \mathrm{MHz}$, $\left.\mathrm{CDCl}_{3}\right) \delta 7.29-7.35(\mathrm{~m}, 4 \mathrm{H}), 6.91(\mathrm{dd}, J=9,2.2 \mathrm{~Hz}, 4 \mathrm{H}), 6.80(\mathrm{~d}, J=7.6 \mathrm{~Hz}, 2 \mathrm{H}), 4.60-4.62(\mathrm{~m}, 2 \mathrm{H})$, $4.48(\mathrm{~s}, 4 \mathrm{H}), 2.46-2.51(\mathrm{~m}, 4 \mathrm{H})$ LC-MS: $m / z=423[\mathrm{M}+\mathrm{H}]^{+}$. 


\section{2-(4-Chlorophenoxy)-N-[(1s,3s)-3-[2-(4-chlorophenoxy)acetamido] cyclobutyl]acetamide (ISRIB-A5)}<smiles>O=C(COc1ccc(Cl)cc1)N[C@H]1C[C@H](NC(=O)COc2ccc(Cl)cc2)C1</smiles>

To a cooled $\left(0^{\circ} \mathrm{C}\right)$ solution of tert-butyl $\mathrm{N}-[(1 \mathrm{~s}, 3 \mathrm{~s})$-3-aminocyclobutyl]carbamate $(0.05 \mathrm{~g}, 0.277 \mathrm{mmol})$ in 1,2-dichloroethane $(1.38 \mathrm{ml})$, was added trifluoroacetic acid $(1.38 \mathrm{ml})$. The reaction mixture was stirred at room temperature for $1.5 \mathrm{hr}$ and then concentrated down to dryness to obtain $100 \mathrm{mg}$ of $(1 \mathrm{~s}, 3 \mathrm{~s})$ cyclobutane-1,3-bis(aminium) ditrifluoroacetate which was used without further purification.

To a solution 4-chlorophenoxyacetic acid $(0.19 \mathrm{~g}, 0.63 \mathrm{mmol})$ in $\mathrm{N}, \mathrm{N}$-dimethylformamide $(1.0 \mathrm{ml})$ were sequentially added 1-hydroxybenzotriazole hydrate $(0.12 \mathrm{~g}, 0.63 \mathrm{mmol}), 1$-(3-dimethylaminopropyl)-3ethylcarbodiimide hydrochloride $(0.175 \mathrm{~g}, 0.63 \mathrm{mmol}),(1 \mathrm{~s}, 3 \mathrm{~s})$-cyclobutane-1,3-bis(aminium) ditrifluoroacetate $(0.1 \mathrm{~g}, 0.31 \mathrm{mmol})$ and $\mathrm{N}, \mathrm{N}$-diisopropylethylamine $(0.34 \mathrm{ml}, 1.91 \mathrm{mmol})$. The reaction mixture was stirred at room temperature for $2 \mathrm{hr}$. The reaction mixture was then diluted with $5 \%$ methanol in dichloromethane, washed with water and brine. The organic layer was dried over magnesium sulfate, filtered and concentrated. The crude mixture was purified by flash column chromatography (40\% acetone/hexanes) to obtain $34 \mathrm{mg} \mathrm{(25 \% )} \mathrm{of} \mathrm{the} \mathrm{title} \mathrm{compound.}{ }^{1} \mathrm{H} \mathrm{NMR} \mathrm{(300} \mathrm{MHz,}$ $\left.\mathrm{CDCl}_{3}\right) \delta 7.26-7.29(\mathrm{~m}, 4 \mathrm{H}), 6.84-6.87(\mathrm{~m}, 4 \mathrm{H}), 6.77(\mathrm{~d}, \mathrm{~J}=6.5 \mathrm{~Hz}, 2 \mathrm{H}), 4.42(\mathrm{~m}, 4 \mathrm{H}), 4.17-4.25$ $(\mathrm{s}, 2 \mathrm{H}), 2.84-2.93(\mathrm{~m}, 2 \mathrm{H}), 2.02-2.12(\mathrm{~m}, 2 \mathrm{H})$ LC-MS: $\mathrm{m} / \mathrm{z}=423[\mathrm{M}+\mathrm{H}]^{+}$.

\section{2-(4-Chlorophenoxy)-N-\{3-[2-(4-chlorophenoxy)acetamido]propyl\} acetamide (ISRIB-A6)}<smiles>O=C(COc1ccc(Cl)cc1)NCCCNC(=O)COc1ccc(Cl)cc1</smiles>

To a solution of 1,3-diaminopropane $(0.017 \mathrm{ml}, 0.2 \mathrm{mmol})$ in tetrahydrofuran $(0.6 \mathrm{ml})$, was added 4chlorophenoxyacetyl chloride $(0.062 \mathrm{ml}, 0.4 \mathrm{mmol})$ and $\mathrm{N}, \mathrm{N}$-diisopropylethylamine $(0.08 \mathrm{ml}, 0.5$ $\mathrm{mmol})$. The reaction mixture was stirred at room temperature for an hour and then partitioned between 1:1 mixture of water/dichloromethane $(20 \mathrm{ml})$. The organic layer was washed with $10 \%$ aqueous potassium hydrogen sulfate, water and brine. The organic phase was then dried over magnesium sulfate, filtered and concentrated to obtain a brownish orange oil. The brownish orange oil was purified by flash column chromatography (5-80\% acetone/dichloromethane) to obtain $41 \mathrm{mg}$ (49\%) of the title compound. ${ }^{1} \mathrm{H}$ NMR $\left(400 \mathrm{MHz} \mathrm{CDCl}_{3}\right) \delta 7.24-7.26(\mathrm{~m}, 4 \mathrm{H}), 7.15$ (br.s, 2H), 6.85-6.87 $(\mathrm{m}, 4 \mathrm{H}$ ), 4.45 (s, 4H), 3.08 (quint, $\mathrm{J}=6.3 \mathrm{~Hz}, 4 \mathrm{H}$ ), 1.37 (quint, $\mathrm{J}=6.2 \mathrm{~Hz}, 2 \mathrm{H}$ ) LC-MS: $\mathrm{m} / \mathrm{z}=411[\mathrm{M}+\mathrm{H}$, $35 \mathrm{Cl}]+, 413[\mathrm{M}+\mathrm{H}, 37 \mathrm{Cl}]+$.

\section{2-(4-Fluorophenoxy)- $\mathrm{N}-[(1 \mathrm{r}, 4 \mathrm{r})-4-[2-(4-c h l o r o p h e n o x y)$ acetamido] cyclohexyl]acetamide (ISRIB-A8)}<smiles>O=C(COc1ccc(F)cc1)N[C@H]1CC[C@H](NC(=O)COc2ccc(Cl)cc2)CC1</smiles> 
Step 1: To a mixture of tert-butyl N-[(1r,4r)-4-aminocyclohexyl]carbamate $(0.750 \mathrm{~g}, 3.5 \mathrm{mmol})$ in THF $(20 \mathrm{ml})$ were sequentially added $\mathrm{N}, \mathrm{N}$-diisopropylethylamine $(0.914 \mathrm{ml}, 5.25 \mathrm{mmol})$ and 4 chlorophenoxyacetyl chloride $(0.573 \mathrm{ml}, 3.78 \mathrm{mmol})$. The reaction mixture was vigorously stirred at room temperature for $3 \mathrm{hr}$ and then diluted with water $(100 \mathrm{ml})$. The precipitate was filtered and the solid was washed with water. The resulting solid was then diluted with diethyl ether and vacuum filtered. The filter cake was washed with diethyl ether. The residual ether was removed under vacuum to afford $1.103 \mathrm{~g}(82 \%)$ of tert-butyl $\mathrm{N}-[(1 \mathrm{r}, 4 \mathrm{r})-4-[2-(4-$ chlorophenoxy)acetamido]cyclohexyl]carbamate as a white solid. ${ }^{1} \mathrm{H}$ NMR $(400 \mathrm{MHz}$, DMSO$\left.\mathrm{d}_{6}\right) \delta 7.88(\mathrm{~d}, J=7.87 \mathrm{~Hz}, 1 \mathrm{H}), 7.25-7.37(\mathrm{~m}, 2 \mathrm{H}), 6.93(\mathrm{~d}, J=8.97 \mathrm{~Hz}, 2 \mathrm{H}), 6.68(\mathrm{~d}, J=7.69 \mathrm{~Hz}$, $1 \mathrm{H}), 4.41(\mathrm{~s}, 2 \mathrm{H}), 3.51(\mathrm{~m}, 1 \mathrm{H}), 3.13$ (br. s., $1 \mathrm{H}), 1.72(\mathrm{t}, \mathrm{J}=13.19 \mathrm{~Hz}, 4 \mathrm{H}), 1.34(\mathrm{~s}, 9 \mathrm{H}), 1.09-1.30$ $(\mathrm{m}, 4 \mathrm{H}) ;$ LC-MS: $\mathrm{m} / \mathrm{z}=405\left[\mathrm{M}+\mathrm{Na},{ }^{35} \mathrm{Cl}\right]+, 407\left[\mathrm{M}+\mathrm{Na},{ }^{37} \mathrm{Cl}\right]+, 765\left[2 \mathrm{M}+\mathrm{H},{ }^{35} \mathrm{Cl} \times 2\right]^{+}, 767$ $\left[2 \mathrm{M}+\mathrm{H},{ }^{35} \mathrm{Cl},{ }^{37} \mathrm{Cl}\right]^{+}$.

Step 2: To a suspension of tert-butyl N-[(1r,4r)-4-[2-(4-chlorophenoxy)acetamido]cyclohexyl] carbamate $(0.5 \mathrm{~g}, 1.31 \mathrm{mmol})$ in dichloromethane $(9 \mathrm{ml})$ were sequentially added triethylsilane $(0.3 \mathrm{ml}, 1.88 \mathrm{mmol})$, water $(0.2 \mathrm{ml}, 11.1 \mathrm{mmol})$, and trifluoroacetic acid $(3.0 \mathrm{ml}, 39.2 \mathrm{mmol})$. The suspension quickly clarified and turned yellow upon addition of trifluoroacetic acid. The reaction mixture was vigorously stirred at room temperature for $30 \mathrm{~min}$ and then the solvent was removed by rotary evaporation. The resulting colorless oil was triturated with diethyl ether. After decanting the ether washes, residual solvent was removed under vacuum to afford 499 $\mathrm{mg}(96 \%)$ of 2-(4-chlorophenoxy)-N-[(1r,4r)-4-aminocyclohexyl]acetamide trifluoroacetic acid as a white solid. ${ }^{1} \mathrm{H}$ NMR $\left(400 \mathrm{MHz}, \mathrm{DMSO}-\mathrm{d}_{6}\right) \delta 7.95(\mathrm{~d}, J=7.87 \mathrm{~Hz}, 1 \mathrm{H}), 7.77$ (br. s., 3H), 7.31 (d, $J=8.97 \mathrm{~Hz}, 2 \mathrm{H}), 6.93(\mathrm{~d}, J=8.97 \mathrm{~Hz}, 2 \mathrm{H}), 4.43(\mathrm{~s}, 2 \mathrm{H}), 3.54(\mathrm{~m}, 1 \mathrm{H}), 2.93$ (br. s., $1 \mathrm{H}), 1.90(\mathrm{~d}, J=$ $9.16 \mathrm{~Hz}, 2 \mathrm{H}), 1.77(\mathrm{~d}, J=9.34 \mathrm{~Hz}, 2 \mathrm{H}), 1.31$ (sxt, $J=11.50 \mathrm{~Hz}, 4 \mathrm{H})$; LC-MS: $\mathrm{m} / \mathrm{z}=283[\mathrm{M}+\mathrm{H}$, $\left.{ }^{35} \mathrm{Cl}\right]^{+}, 285\left[\mathrm{M}+\mathrm{H},{ }^{37} \mathrm{Cl}\right]^{+}$.

Step 3: To a solution of 4-fluorophenoxyacetic acid $(0.009 \mathrm{~g}, 0.050 \mathrm{mmol})$ in N,Ndimethylformamide $(1.0 \mathrm{ml})$ were sequentially added 1 -hydroxybenzotriazole hydrate $(0.009$ g, $0.055 \mathrm{mmol}), 1$-(3-dimethylaminopropyl)-3-ethylcarbodiimide hydrochloride $(0.012 \mathrm{~g}$, $0.057 \mathrm{mmol}), 2$-(4-chlorophenoxy)-N-[(1r,4r)-4-aminocyclohexyl]acetamide trifluoroacetic acid $(0.02 \mathrm{~g}, 0.050 \mathrm{mmol})$ and $\mathrm{N}, \mathrm{N}$-diisopropylethylamine $(0.013 \mathrm{ml}, 0.12 \mathrm{mmol})$. The reaction mixture was subjected to conditions described in procedure $A$ to obtain $14 \mathrm{mg}$ $(60 \%)$ of the title compound as a white solid. ${ }^{1} \mathrm{H}$ NMR (400 MHz, DMSO-d6) $\delta$ 7.88-7.92 (M, $2 \mathrm{H}), 7.31(\mathrm{~d}, \mathrm{~J}=9 \mathrm{~Hz}, 2 \mathrm{H}), 7.10(\mathrm{t}, \mathrm{J}=8.8 \mathrm{~Hz}, 2 \mathrm{H}), 6.92-6.95(\mathrm{~m}, 4 \mathrm{H}), 4.39-4.42(\mathrm{~m}, 4 \mathrm{H}), 3.57$ (br. s, 2H), $1.74(\mathrm{~d}, \mathrm{~J}=5.9 \mathrm{~Hz}, 4 \mathrm{H}), 1.29-1.33(\mathrm{~m}, 4 \mathrm{H})$ LC-MS: $\mathrm{m} / \mathrm{z}=435[\mathrm{M}+\mathrm{H}, 35 \mathrm{Cl}]+, 437$ $[\mathrm{M}+\mathrm{H}, 37 \mathrm{Cl}]+$.

\section{2-(4-Fluorophenoxy)- $\mathrm{N}-[(1 \mathrm{r}, 4 \mathrm{r})-4$-[2-(4-fluorophenoxy)acetamido] cyclohexyl]acetamide (ISRIB-A9)}<smiles>O=C(COc1ccc(F)cc1)N[C@H]1CC[C@H](NC(=O)COc2ccc(F)cc2)CC1</smiles>

To a solution 4-fluorophenoxyacetic acid $(0.12 \mathrm{~g}, 0.7 \mathrm{mmol})$ in $\mathrm{N}, \mathrm{N}$-dimethylformamide $(1.0 \mathrm{ml})$ were sequentially added 1-hydroxybenzotriazole hydrate $(0.094 \mathrm{~g}, 0.7 \mathrm{mmol}), 1$-(3-dimethylaminopropyl)-3ethylcarbodiimide hydrochloride $(0.140 \mathrm{~g}, 0.7 \mathrm{mmol}),(1 \mathrm{r}, 4 \mathrm{r})$-cyclohexane-1,4-diamine $(0.040 \mathrm{~g}, 0.35$ $\mathrm{mmol}$ ) and N,N-diisopropylethylamine $(0.372 \mathrm{ml}, 2.1 \mathrm{mmol})$. The reaction mixture was subjected to conditions described in procedure $\mathrm{B}$ to afford $73 \mathrm{mg} \mathrm{(50 \% )}$ of the title compound. ${ }^{1} \mathrm{H}$ NMR (300 MHz, $\left.\mathrm{CDCl}_{3}\right) \delta 7.02(\mathrm{t}, J=8.3 \mathrm{~Hz}, 4 \mathrm{H}), 6.89-6.90(\mathrm{~m}, 4 \mathrm{H}), 6.38(\mathrm{~d}, J=7.5 \mathrm{~Hz}, 2 \mathrm{H}), 4.43(\mathrm{~s}, 4 \mathrm{H}), 3.88(\mathrm{br} . \mathrm{s}, 2 \mathrm{H})$, $2.07(d, J=5.7 \mathrm{~Hz}, 4 \mathrm{H}), 1.36-1.39(\mathrm{~m}, 4 \mathrm{H})$ LC-MS: $m / z=419[\mathrm{M}+\mathrm{H}]^{+}$. 


\section{2-(4-Methylphenoxy)-N-[(1r,4r)-4-[2-(4-chlorophenoxy)acetamido] cyclohexyl]acetamide (ISRIB-A10)}<smiles>Cc1ccc(OCC(=O)NC2CCC(NC(=O)COc3ccc(Cl)cc3)CC2)cc1</smiles>

To a solution 4-methyl-phenoxyacetic acid $(0.016 \mathrm{~g}, 0.101 \mathrm{mmol})$ in $\mathrm{N}, \mathrm{N}$-dimethylformamide $(1.0 \mathrm{ml})$ were sequentially added 1-hydroxybenzotriazole hydrate $(0.014 \mathrm{~g}, 0.101 \mathrm{mmol}), 1$-(3-dimethylaminopropyl)-3ethylcarbodiimide hydrochloride $(0.02 \mathrm{~g}, 0.101 \mathrm{mmol}), 2$-(4-chlorophenoxy)-N-[(1r,4r)-4-aminocyclohexyl] acetamide trifluoroacetic acid $(0.04 \mathrm{~g}, 0.101 \mathrm{mmol})$ and $\mathrm{N}, \mathrm{N}$-diisopropylethylamine $(0.06 \mathrm{ml}, 0.303 \mathrm{mmol})$. The reaction mixture was subjected to conditions described in procedure $A$ to obtain $7 \mathrm{mg}(16 \%)$ of the title compound as a white solid. ${ }^{1} \mathrm{H}$ NMR $(400 \mathrm{MHz}, \mathrm{DMSO}-\mathrm{d} 6) \delta 7.91(\mathrm{~d}, \mathrm{~J}=8 \mathrm{~Hz}, 1 \mathrm{H}), 7.84(\mathrm{~d}, \mathrm{~J}=7.8 \mathrm{~Hz}$, $1 \mathrm{H}), 7.31(\mathrm{~d}, \mathrm{~J}=8.8 \mathrm{~Hz}, 2 \mathrm{H}), 7.06(\mathrm{t}, \mathrm{J}=8.3 \mathrm{~Hz}, 2 \mathrm{H}), 6.94(\mathrm{~d}, \mathrm{~J}=8.8 \mathrm{~Hz}, 2 \mathrm{H}), 6.80(\mathrm{~d}, \mathrm{~J}=8.4 \mathrm{~Hz}, 2 \mathrm{H})$, $4.42(\mathrm{~s}, 2 \mathrm{H}), 4.35$ (s, 2H), 3.56 (br. s, 2H), 2.20 (s, 3H), 1.73 ( $\mathrm{d}, \mathrm{J}=6.6 \mathrm{~Hz}, 4 \mathrm{H}), 1.22-1.33$ (m, 4H) LC-MS: $\mathrm{m} / \mathrm{z}=431[\mathrm{M}+\mathrm{H}]^{+}$.

\section{2-(4-Methylphenoxy)-N-[(1r,4r)-4-[2-(4-methylphenoxy)acetamido] cyclohexyl]acetamide (ISRIB-A11)}

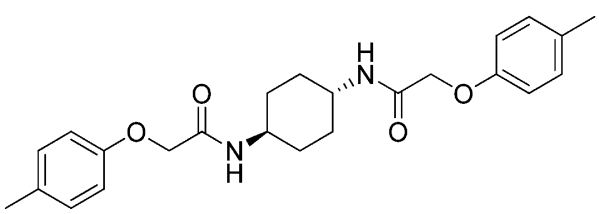

To a solution 4-methylphenoxyacetic acid $(0.116 \mathrm{~g}, 0.7 \mathrm{mmol})$ in N,N-dimethylformamide $(1.0 \mathrm{ml})$ were sequentially added 1-hydroxybenzotriazole hydrate $(0.094 \mathrm{~g}, 0.7 \mathrm{mmol})$, 1-(3dimethylaminopropyl)-3-ethylcarbodiimide hydrochloride $(0.14 \mathrm{~g}, 0.7 \mathrm{mmol}),(1 \mathrm{r}, 4 \mathrm{r})$-cyclohexane1,4-diamine $(0.04 \mathrm{~g}, 0.35 \mathrm{mmol})$ and $\mathrm{N}, \mathrm{N}$-diisopropylethylamine $(0.372 \mathrm{ml}, 2.1 \mathrm{mmol})$. The reaction mixture was stirred at $52^{\circ} \mathrm{C}$ for $24 \mathrm{hr}$ and then subjected to conditions described in procedure $\mathrm{B}$ to afford $84 \mathrm{mg}(58 \%)$ of the title compound. ${ }^{1} \mathrm{H}$ NMR $\left(400 \mathrm{MHz}, \mathrm{DMSO}-\mathrm{d}_{6}\right) \delta 7.84(\mathrm{~d}, \mathrm{~J}=6.8 \mathrm{~Hz}, 2 \mathrm{H})$, $7.05(\mathrm{~d}, J=6.8 \mathrm{~Hz}, 4 \mathrm{H}), 6.80(\mathrm{~d}, J=6.6 \mathrm{~Hz}, 4 \mathrm{H}), 4.35(\mathrm{~s}, 4 \mathrm{H}), 3.56$ (br. s, 2H), 2.19 (s, 6H), 1.73 (br. s, $4 \mathrm{H}), 1.31$ (br.s, 4H) LC-MS: $m / z=411[\mathrm{M}+\mathrm{H}]^{+}$.

\section{2-(4-Cyanophenoxy)-N-[(1r,4r)-4-[2-(4-chlorophenoxy)acetamido] cyclohexyl]acetamide (ISRIB-A12)}<smiles>N#Cc1ccc(OCC(=O)NC2CCC(NC(=O)COc3ccc(Cl)cc3)CC2)cc1</smiles>

To a solution 4-cyanophenoxyacetic acid $(0.009 \mathrm{~g}, 0.050 \mathrm{mmol})$ in $\mathrm{N}, \mathrm{N}$-dimethylformamide $(1.0 \mathrm{ml})$ were sequentially added 1-hydroxybenzotriazole hydrate $(0.009 \mathrm{~g}, 0.055 \mathrm{mmol})$, 1-(3dimethylaminopropyl)-3-ethylcarbodiimide hydrochloride $(0.012 \quad \mathrm{~g}, 0.057 \mathrm{mmol}), 2-(4-$ chlorophenoxy)-N-[(1r,4r)-4-aminocyclohexyl]acetamide trifluoroacetic acid (0.02 $\mathrm{g}, 0.050 \mathrm{mmol})$ and $\mathrm{N}, \mathrm{N}$-diisopropylethylamine $(0.013 \mathrm{ml}, 0.12 \mathrm{mmol})$. The reaction mixture was subjected to conditions described in procedure A to obtain $14 \mathrm{mg} \mathrm{(65 \% )} \mathrm{of} \mathrm{the} \mathrm{title} \mathrm{compound} \mathrm{as} \mathrm{a} \mathrm{beige} \mathrm{solid.} 1 \mathrm{H}$ NMR (400 MHz, DMSO-d6) $\delta 7.99(\mathrm{~d}, \mathrm{~J}=7.9 \mathrm{~Hz}, 1 \mathrm{H}), 7.91(\mathrm{~d}, \mathrm{~J}=8.1 \mathrm{~Hz}, 1 \mathrm{H}), 7.76(\mathrm{~d}, \mathrm{~J}=8.8 \mathrm{~Hz}, 1 \mathrm{H})$, 
$7.31(\mathrm{~d}, \mathrm{~J}=9.1 \mathrm{~Hz}, 1 \mathrm{H}), 7.07(\mathrm{~d}, \mathrm{~J}=8.8 \mathrm{~Hz}, 2 \mathrm{H}), 6.94(\mathrm{~d}, \mathrm{~J}=8.8 \mathrm{~Hz}, 2 \mathrm{H}), 4.55(\mathrm{~s}, 2 \mathrm{H}), 4.42(\mathrm{~s}, 2 \mathrm{H}), 3.56$ (br. s, 2H), $1.74(\mathrm{~d}, \mathrm{~J}=7.7 \mathrm{~Hz}, 4 \mathrm{H}), 1.28-1.32(\mathrm{~m}, 4 \mathrm{H})$ LC-MS: $\mathrm{m} / \mathrm{z}=442[\mathrm{M}+\mathrm{H}, 35 \mathrm{Cl}]+, 444[\mathrm{M}+\mathrm{H}$, $37 \mathrm{Cl}]+$.

\section{2-(4-Cyanophenoxy)- $\mathrm{N}-[(1 \mathrm{r}, 4 \mathrm{r})-4-[2-(4-c y a n o p h e n o x y)$ acetamido] cyclohexyl]acetamide (ISRIB-A13)}<smiles>N#Cc1ccc(OCC(=O)NC2CCC(NC(=O)COc3ccc([N+]#N)cc3)CC2)cc1</smiles>

To a solution 4-cyanophenoxyacetic acid $(0.124 \mathrm{~g}, 0.7 \mathrm{mmol})$ in $\mathrm{N}, \mathrm{N}$-dimethylformamide $(1.0 \mathrm{ml})$ were sequentially added 1 -hydroxybenzotriazole hydrate $(0.094 \mathrm{~g}, 0.7 \mathrm{mmol}), 1$-(3-dimethylaminopropyl)-3ethylcarbodiimide hydrochloride $(0.14 \mathrm{~g}, 0.7 \mathrm{mmol}),(1 \mathrm{r}, 4 \mathrm{r})$-cyclohexane-1,4-diamine $(0.04 \mathrm{~g}$, $0.35 \mathrm{mmol}$ ) and $\mathrm{N}, \mathrm{N}$-diisopropylethylamine $(0.372 \mathrm{ml}, 2.1 \mathrm{mmol})$. The reaction mixture was subjected to conditions described in procedure $B$ to afford $54 \mathrm{mg} \mathrm{(36 \% )} \mathrm{of} \mathrm{the} \mathrm{title} \mathrm{compound.}{ }^{1} \mathrm{H}$ NMR (300 $\left.\mathrm{MHz}, \mathrm{DMSO}-\mathrm{d}_{6}\right) \delta 8.01(\mathrm{~d}, J=5.8 \mathrm{~Hz}, 2 \mathrm{H}), 7.76(\mathrm{~d}, J=6.8 \mathrm{~Hz}, 4 \mathrm{H}), 7.08(\mathrm{~d}, J=6.8 \mathrm{~Hz}, 4 \mathrm{H}), 4.55(\mathrm{~s}, 4 \mathrm{H})$, 3.56 (br. s, 2H), 1.75 (br. s, 4H), 1.31 (br. s, 4H) LC-MS: $m / z=433[\mathrm{M}+\mathrm{H}]^{+}$.

\section{2-(3,4-Dichlorophenoxy)-N-[(1r,4r)-4-[2-(4-chlorophenoxy)acetamido] cyclohexyl]acetamide (ISRIB-A14)}<smiles>O=C(COc1ccc(Cl)cc1)N[C@H]1CC[C@H](NC(=O)COc2ccc(Cl)c(Cl)c2)CC1</smiles>

To a solution 3,4-dichlorophenoxyacetic acid $(0.011 \mathrm{~g}, 0.050 \mathrm{mmol})$ in $\mathrm{N}, \mathrm{N}$-dimethylformamide $(1.0 \mathrm{ml})$ were sequentially added 1-hydroxybenzotriazole hydrate $(0.009 \mathrm{~g}, 0.055 \mathrm{mmol}), 1$-(3-dimethylaminopropyl)-3ethylcarbodiimide hydrochloride $(0.012 \mathrm{~g}, 0.057 \mathrm{mmol}), 2-(4-c h l o r o p h e n o x y)-\mathrm{N}-[(1 \mathrm{r}, 4 \mathrm{r})-4$-aminocyclohexyl] acetamide trifluoroacetic acid $(0.020 \mathrm{~g}, 0.050 \mathrm{mmol})$ and $\mathrm{N}, \mathrm{N}$-diisopropylethylamine $(0.013 \mathrm{ml}, 0.12 \mathrm{mmol})$. The reaction mixture was subjected to conditions described in procedure A to obtain $21 \mathrm{mg}(86 \%)$ of the title compound as a white solid. ${ }^{1} \mathrm{H} \mathrm{NMR}\left(400 \mathrm{MHz}, \mathrm{DMSO}-\mathrm{d}_{6}\right) \delta 7.94(\mathrm{~d}, J=8.2 \mathrm{~Hz}, 1 \mathrm{H}), 7.91(\mathrm{~d}, J=8.2 \mathrm{~Hz}$, 1H), $7.51(\mathrm{~d}, J=8.8 \mathrm{~Hz}, 1 \mathrm{H}), 7.31(\mathrm{~d}, J=9 \mathrm{~Hz}, 2 \mathrm{H}), 7.22(\mathrm{~d}, J=2.9 \mathrm{~Hz}, 1 \mathrm{H}), 6.92-6.95(\mathrm{~m}, 3 \mathrm{H}), 4.48(\mathrm{~s}, 2 \mathrm{H})$, $4.42(\mathrm{~s}, 2 \mathrm{H}), 3.56$ (br. s, 2H), $1.74(\mathrm{~d}, \mathrm{~J}=6 \mathrm{~Hz}, 4 \mathrm{H}), 1.26-1.31(\mathrm{~m}, 4 \mathrm{H}) \mathrm{LC}-\mathrm{MS}: \mathrm{m} / \mathrm{z}=485\left[\mathrm{M}+\mathrm{H},{ }^{35} \mathrm{Cl}\right]^{+}, 487$ $\left[\mathrm{M}+\mathrm{H},{ }^{37} \mathrm{Cl}\right]^{+}$.

\section{2-(3,4-Dichlorophenoxy)-N-[(1r,4r)-4-[2-(3,4-dichlorophenoxy)acetamido] cyclohexyl]acetamide (ISRIB-A15)}<smiles>O=C(COc1ccc(Cl)c(Cl)c1)N[C@H]1CC[C@H](NC(=O)COc2ccc(Cl)c(Cl)c2)CC1</smiles> 
To a solution of $(1 \mathrm{r}, 4 \mathrm{r})$-cyclohexane-1,4-diamine $(0.025 \mathrm{~g}, 0.2 \mathrm{mmol})$ in $\mathrm{N}, \mathrm{N}$-dimethylformamide (1 ml) were added 3,4-dichlorophenoxyacetic acid $(0.097 \mathrm{~g}, 0.4 \mathrm{mmol}), 1$-[bis(dimethylamino)methylene]$1 \mathrm{H}-1,2,3$-triazolo[4,5-b]pyridinium 3-oxid hexafluorophosphate $(0.175 \mathrm{~g}, 0.5 \mathrm{mmol})$ and $\mathrm{N}, \mathrm{N}$ diisopropylethylamine $(0.153 \mathrm{ml}, 0.9 \mathrm{mmol})$. The reaction mixture was subjected to conditions described in procedure $\mathrm{C}$ to obtain $107 \mathrm{mg}(94 \%)$ of the title compound as a cream colored solid. ${ }^{1} \mathrm{H} \mathrm{NMR}\left(400 \mathrm{MHz}_{2} \mathrm{CDCl}_{3}\right) \delta 7.37(\mathrm{~d}, J=8.8 \mathrm{~Hz}, 2 \mathrm{H}), 7.04(\mathrm{~s}, 2 \mathrm{H}), 6.78(\mathrm{~d}, J=8.8 \mathrm{~Hz}, 2 \mathrm{H}), 6.26(\mathrm{~d}, J=$ $8.1 \mathrm{~Hz}, 2 \mathrm{H}), 4.42(\mathrm{~s}, 4 \mathrm{H}), 3.85$ (br. $\mathrm{s}, 2 \mathrm{H}), 2.05(\mathrm{~d}, \mathrm{~J}=6 \mathrm{~Hz}, 4 \mathrm{H}), 1.31-1.39(\mathrm{~m}, 4 \mathrm{H}) ; \mathrm{LC}-\mathrm{MS}: \mathrm{m} / \mathrm{z}=519$ $\left[\mathrm{M}+\mathrm{H},{ }^{35} \mathrm{Cl}\right]^{+}, 521\left[\mathrm{M}+\mathrm{H},{ }^{37} \mathrm{Cl}\right]^{+}$.

\section{2-(4-Chloro-3-fluorophenoxy)-N-[(1r,4r)-4-[2-(4-chlorophenoxy) acetamido]cyclohexyl]acetamide (ISRIB-A16)}<smiles>O=C(COc1ccc(Cl)cc1)N[C@H]1CC[C@H](NC(=O)COc2ccc(Cl)c(F)c2)CC1</smiles>

Step 1: To a cooled solution $\left(0^{\circ} \mathrm{C}\right)$ of $(1 \mathrm{r}, 4 \mathrm{r})$-4-[2-(4-chlorophenoxy)acetamido]cyclohexan-1aminium trifluoroacetate $(0.550 \mathrm{~g}, 1.4 \mathrm{mmol})$ in THF and $\mathrm{N}, \mathrm{N}$-diisopropylethylamine $(0.966 \mathrm{ml}$, $5.5 \mathrm{mmol}$ ) slowly added chloroacetyl chloride $(0.121 \mathrm{ml}, 1.5 \mathrm{mmol})$. The mixture was stirred at ambient temperature for $20 \mathrm{~min}$. The reaction mixture was diluted in dichloromethane, washed with $0.1 \mathrm{~N}$ hydrochloric acid, water and brine. The organic layer was dried over magnesium sulfate, filtered and concentrated in a rotary evaporator to obtain about $430 \mathrm{mg}$ of crude 2-(4chlorophenoxy)-N-[(1r,4r)-4-(2-chloroacetamido)cyclohexyl]acetamide that was used without further purification.

Step 2: To a suspension of 2-(4-chlorophenoxy)-N-[(1r,4r)-4-(2-chloroacetamido)cyclohexyl] acetamide $(0.036 \mathrm{~g}, 0.1 \mathrm{mmol})$ and 4-chloro-3-fluorophenol $(0.015 \mathrm{~g}, 0.1 \mathrm{mmol})$ in acetone $(1.0 \mathrm{ml})$, added potassium carbonate $(0.021 \mathrm{~g}, 0.2 \mathrm{mmol})$ and stirred at $120^{\circ} \mathrm{C}$ in the microwave reactor for $20 \mathrm{~min}$. The reaction mixture was concentrated down and suspended in water $(10 \mathrm{ml})$. The mixture was vigorously vortexed then centrifuged, and the water was decanted. This washing protocol was repeated with water and then with diethyl ether $(10 \mathrm{ml})$. The wet solid was dissolved in dichloromethane $(10 \mathrm{ml})$ and dried over anhydrous magnesium sulfate. The solids were removed by filtration, and the filtrate was concentrated by rotary evaporation to afford $28 \mathrm{mg}(60 \%)$ of the title compound as a tan solid. ${ }^{1} \mathrm{H}$ NMR $\left(400 \mathrm{MHz}, \mathrm{DMSO}-\mathrm{d}_{6}\right) \delta 7.9$ $(t, J=8.9 \mathrm{~Hz}, 2 \mathrm{H}), 7.46(\mathrm{t}, J=8.9 \mathrm{~Hz}, 1 \mathrm{H}), 7.31(\mathrm{~d}, J=9 \mathrm{~Hz}, 2 \mathrm{H}), 7.03(\mathrm{dd}, J=11.4,2.7 \mathrm{~Hz}, 1 \mathrm{H})$, $6.94(\mathrm{~d}, J=9 \mathrm{~Hz}, 2 \mathrm{H}), 6.81(\mathrm{dd}, J=8.5,2.3 \mathrm{~Hz}, 1 \mathrm{H}), 4.46(\mathrm{~s}, 2 \mathrm{H}), 4.42(\mathrm{~s}, 2 \mathrm{H}), 1.74(\mathrm{~d}, J=6.2 \mathrm{~Hz}$, $4 \mathrm{H}), 1.29-1.35(\mathrm{~m}, 4 \mathrm{H})$ LC-MS: $\mathrm{m} / \mathrm{z}=469\left[\mathrm{M}+\mathrm{H},{ }^{35} \mathrm{Cl}\right]+471\left[\mathrm{M}+\mathrm{H},{ }^{37} \mathrm{Cl}\right]^{+}$.

\section{2-(4-Chloro-3-fluorophenoxy)-N-[(1r,4r)-4-[2-(4-chloro-3-fluorophenoxy) acetamido]cyclohexyl]acetamide (ISRIB-A17)}<smiles>O=C(COc1ccc(Cl)c(F)c1)N[C@H]1CC[C@H](NC(=O)COc2ccc(Cl)c(F)c2)CC1</smiles> 
Step 1: To a solution 4-chloro-3-fluorophenol $(0.100 \mathrm{~g}, 0.7 \mathrm{mmol})$ in N,N-dimethylformamide $(2 \mathrm{ml})$, were added potassium carbonate $(0.189 \mathrm{~g}, 1.4 \mathrm{mmol})$ and tert-butyl bromoacetate $(0.111 \mathrm{ml}, 0.8 \mathrm{mmol})$ and stirred at $65^{\circ} \mathrm{C}$ for $2 \mathrm{hr}$. The reaction mixture was diluted with ethyl acetate $(10 \mathrm{ml})$, washed with water $(3 \times 10 \mathrm{ml})$ and brine $(10 \mathrm{ml})$. The organic layer was dried over magnesium sulfate and concentrated in a rotary evaporator to obtain $177 \mathrm{mg}$ of tert-butyl 2-(4-chloro-3-fluorophenoxy)acetate as a colorless oil which was used without further purification.

Step 2: To a solution of tert-butyl 2-(4-chloro-3-fluorophenoxy)acetate (177 mg, $0.7 \mathrm{mmol}$ ) in methanol/water $(4.5 \mathrm{ml}, 2: 1)$ was added aqueous $5 \mathrm{~N} \mathrm{NaOH}$ solution $(0.7 \mathrm{ml}, 3.5 \mathrm{mmol})$ and stirred at ambient temperature for an hour. The reaction mixture was concentrated in a rotary evaporator to remove methanol, diluted with water $(5 \mathrm{ml})$ and extracted with ethyl acetate $(5 \mathrm{ml})$. The aqueous layer was adjusted to about $\mathrm{pH} 2$ with $1 \mathrm{~N}$ hydrochloric acid and extracted with ethyl acetate $(3 \times 5 \mathrm{ml})$. The organic extract was washed with brine $(5 \mathrm{ml})$, dried over magnesium sulfate and concentrated to obtain $108 \mathrm{mg}$ of 2-(4-chloro-3-fluorophenoxy)acetic acid as a white solid which was used without further purification.

Step 3: To a solution of $(1 \mathrm{r}, 4 \mathrm{r})$-cyclohexane-1,4-diamine $(0.02 \mathrm{~g}, 0.2 \mathrm{mmol})$ in $\mathrm{N}, \mathrm{N}$ -

dimethylformamide $(1 \mathrm{ml})$ were added 2-(4-chloro-3-fluorophenoxy)acetic acid $(0.072 \mathrm{~g}, 0.4$ $\mathrm{mmol}$ ), 1-[bis(dimethylamino)methylene]-1H-1,2,3-triazolo[4,5-b]pyridinium 3-oxid hexafluorophosphate $(0.14 \mathrm{~g}, 0.4 \mathrm{mmol})$ and $\mathrm{N}, \mathrm{N}$-diisopropylethylamine $(0.122 \mathrm{ml}, 0.7 \mathrm{mmol})$. The reaction mixture was subjected to conditions described in procedure $\mathrm{C}$ to obtain $85 \mathrm{mg}(>95 \%)$ of the title compound as a white solid. ${ }^{1} \mathrm{H}$ NMR $\left(400 \mathrm{MHz}, \mathrm{DMSO}-\mathrm{d}_{6}\right) \delta 7.23-7.28(\mathrm{~m}, 2 \mathrm{H}), 6.72(\mathrm{~d}, \mathrm{~J}=8$ $\mathrm{Hz}, 2 \mathrm{H}), 6.61-6.64(\mathrm{~m}, 4 \mathrm{H}), 4.36(\mathrm{~s}, 4 \mathrm{H}), 3.56(\mathrm{~m}, 2 \mathrm{H}), 1.95(\mathrm{~d}, \mathrm{~J}=6.2 \mathrm{~Hz}, 4 \mathrm{H}), 1.28-1.33(\mathrm{~m}, 4 \mathrm{H})$; LC-MS: $\mathrm{m} / \mathrm{z}=487\left[\mathrm{M}+\mathrm{H},{ }^{35} \mathrm{Cl}\right]^{+}, 489\left[\mathrm{M}+\mathrm{H},{ }^{37} \mathrm{Cl}\right]^{+}$.

\section{3-(4-Chlorophenyl)-N-[(1r,4r)-4-[3-(4-chlorophenyl)propanamido] cyclohexyl]propanamide (ISRIB-A18)}

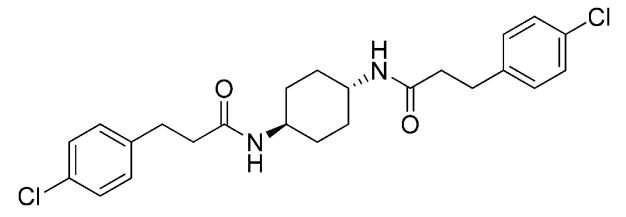

To a solution 3-(4-chlorophenyl)propionic acid $(0.129 \mathrm{~g}, 0.7 \mathrm{mmol})$ in N,N-dimethylformamide $(1.0 \mathrm{ml})$ were sequentially added 1-hydroxybenzotriazole hydrate $(0.094 \mathrm{~g}, 0.7 \mathrm{mmol})$, 1-(3dimethylaminopropyl)-3-ethylcarbodiimide hydrochloride $(0.14 \mathrm{~g}, 0.7 \mathrm{mmol}),(1 \mathrm{r}, 4 \mathrm{r})$-cyclohexane1,4-diamine $(0.04 \mathrm{~g}, 0.35 \mathrm{mmol})$ and $\mathrm{N}, \mathrm{N}$-diisopropylethylamine $(0.372 \mathrm{ml}, 2.1 \mathrm{mmol})$. The reaction mixture was stirred at $52^{\circ} \mathrm{C}$ for $18 \mathrm{hr}$ and then subjected to conditions described in procedure $\mathrm{B}$ to afford $103 \mathrm{mg}(66 \%)$ of the title compound. ${ }^{1} \mathrm{H}$ NMR $\left(400 \mathrm{MHz}, \mathrm{DMSO}-\mathrm{d}_{6}\right) \delta 7.65(\mathrm{~d}, \mathrm{~J}=7.5 \mathrm{~Hz}, 2 \mathrm{H})$, $7.28(\mathrm{~d}, J=8.1 \mathrm{~Hz}, 4 \mathrm{H}), 7.17-7.19(\mathrm{~m}, 4 \mathrm{H}), 3.41(\mathrm{br} . \mathrm{s}, 2 \mathrm{H}), 2.73-2.76(\mathrm{~m}, 4 \mathrm{H}), 2.26-2.30(\mathrm{~m}, 4 \mathrm{H})$, 1.66-1.68 (m, 4H), 1.10-1.12 (m, 4H) LC-MS: $\left.\mathrm{m} / \mathrm{z}=447\left[\mathrm{M}+\mathrm{H},{ }^{35} \mathrm{Cl}\right]\right]^{+}, 449\left[\mathrm{M}+\mathrm{H},{ }^{37} \mathrm{Cl}\right]^{+}$.

\section{Acknowledgements}

We are indebted to Dr Shiva Malek (Genentech) for suggesting the use of thermodenaturation to monitor ligand-target engagement. We thank Margaret Elvekrog for her technical advice and Diego Acosta-Alvear for reagents, and Jason Gestwicki for invaluable advice on the ISRIB SAR.

\section{Additional information}

Competing interests

CS: Inventors on UC patent application PCT/US2014/029568. Title: Modulators of the elF2a pathway. $\mathrm{BRH}$ : Inventors on UC patent application PCT/US2014/029568. Title: Modulators of the elF2a 
pathway. PV: Inventors on UC patent application PCT/US2014/029568. Title: Modulators of the elF2a pathway. ARR: Inventors on UC patent application PCT/US2014/029568. Title: Modulators of the elF2a pathway. PW: Inventors on UC patent application PCT/US2014/029568. Title: Modulators of the elF2a pathway. The other authors declare that no competing interests exist.

Funding

\begin{tabular}{ll} 
Funder & Author \\
\hline Howard Hughes Medical Institute & Carmela Sidrauski, Jordan C Tsai, \\
(HHMI) & Martin Kampmann, Aaron S \\
& Mendez, Jonathan S Weissman, \\
& Peter Walter
\end{tabular}

The funder had no role in study design, data collection and interpretation, or the decision to submit the work for publication.

\section{Author contributions}

CS, JCT, MK, Conception and design, Acquisition of data, Analysis and interpretation of data, Drafting or revising the article; $\mathrm{BRH}$, Conception and design, Acquisition of data, Analysis and interpretation of data; PV, PJ, BWN, ELT, EV, Acquisition of data, Analysis and interpretation of data; MS, Acquisition of data, Contributed unpublished essential data or reagents; ASM, Analysis and interpretation of data, Contributed unpublished essential data or reagents; JRJ, Conception and design, Analysis and interpretation of data; NJK, CSF, JSW, Analysis and interpretation of data, Drafting or revising the article; ARR, PW, Conception and design, Analysis and interpretation of data, Drafting or revising the article

Author ORCIDs

Jordan C Tsai, (iD http://orcid.org/0000-0001-5202-722X

Martin Kampmann, (iD http://orcid.org/0000-0002-3819-7019

Erik Verschueren, (iD http://orcid.org/0000-0001-5842-6344

\section{References}

Baleriola J, Walker CA, Jean YY, Crary JF, Troy CM, Nagy PL, Hengst U. 2014. Axonally synthesized ATF4 transmits a neurodegenerative signal across brain regions. Cell 158:1159-1172. doi: 10.1016/j.cell.2014.07.001.

Bassik MC, Kampmann M, Lebbink RJ, Wang S, Hein MY, Poser I, Weibezahn J, Horlbeck MA, Chen S, Mann M, Hyman AA, Leproust EM, McManus MT, Weissman JS. 2013. A systematic mammalian genetic interaction map reveals pathways underlying ricin susceptibility. Cell 152:909-922. doi: 10.1016/j.cell.2013.01.030.

Bogorad AM, Xia B, Sandor DG, Mamonov AB, Cafarella TR, Jehle S, Vajda S, Kozakov D, Marintchev A. 2014. Insights into the architecture of the elF2B $\alpha / \beta / \delta$ regulatory subcomplex. Biochemistry 53:3432-3445. doi: 10.1021/bi500346u.

Borck G, Shin BS, Stiller B, Mimouni-Bloch A, Thiele H, Kim JR, Thakur M, Skinner C, Aschenbach L, Smirin-Yosef P, Har-Zahav A, Nürnberg G, Altmüller J, Frommolt P, Hofmann K, Konen O, Nürnberg P, Munnich A, Schwartz CE, Gothelf D, Colleaux L, Dever TE, Kubisch C, Basel-Vanagaite L. 2012. elF2 $\gamma$ mutation that disrupts elF2 complex integrity links intellectual disability to impaired translation initiation. Molecular Cell 48:641-646. doi: 10.1016/j. molcel.2012.09.005.

Chen A, Muzzio IA, Malleret G, Bartsch D, Verbitsky M, Pavlidis P, Yonan AL, Vronskaya S, Grody MB, Cepeda I, Gilliam TC, Kandel ER. 2003. Inducible enhancement of memory storage and synaptic plasticity in transgenic mice expressing an inhibitor of ATF4 (CREB-2) and C/EBP proteins. Neuron 39:655-669. doi: 10.1016/S0896-6273(03)00501-4.

Cox J, Mann M. 2008. MaxQuant enables high peptide identification rates, individualized p.p.b.-range mass accuracies and proteome-wide protein quantification. Nature Biotechnology 26:1367-1372. doi: 10.1038/nbt.1511.

Dev K, Qiu H, Dong J, Zhang F, Barthlme D, Hinnebusch AG. 2010. The beta/Gcd7 subunit of eukaryotic translation initiation factor 2B (elF2B), a guanine nucleotide exchange factor, is crucial for binding elF2 in vivo. Molecular and Cellular Biology 30:5218-5233. doi: 10.1128/MCB.00265-10.

Di Prisco GV, Huang W, Buffington SA, Hsu CC, Bonnen PE, Placzek AN, Sidrauski C, Krnjević K, Kaufman RJ, Walter P, Costa-Mattioli M. 2014. Translational control of mGluR-dependent long-term depression and objectplace learning by elF2 $\alpha$. Nature Neuroscience 17:1073-1082. doi: 10.1038/nn.3754.

Fogli A, Boespflug-Tanguy O. 2006. The large spectrum of elF2B-related diseases. Biochemical Society Transactions 34:22-29. doi: 10.1042/BST20060022.

Fraser CS, Berry KE, Hershey JW, Doudna JA. 2007. elF3j is located in the decoding center of the human 40S ribosomal subunit. Molecular Cell 26:811-819. doi: 10.1016/j.molcel.2007.05.019.

Gordiyenko Y, Schmidt C, Jennings MD, Matak-Vinkovic D, Pavitt GD, Robinson CV. 2014. elF2B is a decameric guanine nucleotide exchange factor with a $\gamma 2 \varepsilon 2$ tetrameric core. Nature Communications 5:3902. doi: 10.1038/ ncomms4902. 
Harding HP, Novoa I, Zhang Y, Zeng H, Wek R, Schapira M, Ron D. 2000. Regulated translation initiation controls stressinduced gene expression in mammalian cells. Molecular Cell 6:1099-1108. doi: 10.1016/S1097-2765(00)00108-8.

Harding HP, Zhang Y, Zeng H, Novoa I, Lu PD, Calfon M, Sadri N, Yun C, Popko B, Paules R, Stojdl DF, Bell JC, Hettmann T, Leiden JM, Ron D. 2003. An integrated stress response regulates amino acid metabolism and resistance to oxidative stress. Molecular Cell 11:619-633. doi: 10.1016/S1097-2765(03)00105-9.

Hinnebusch AG, Lorsch JR. 2012. The mechanism of eukaryotic translation initiation: new insights and challenges. Cold Spring Harbor Perspectives in Biology 4:a011544. doi: 10.1101/cshperspect.a011544.

Jennings MD, Pavitt GD. 2014. A new function and complexity for protein translation initiation factor elF2B. Cell Cycle 13:2660-2665. doi: 10.4161/15384101.2014.948797.

Jennings MD, Pavitt GD. 2015. elF5 has GDI activity necessary for translational control by elF2 phosphorylation. Nature 465:378-381. doi: 10.1038/nature09003.

Jennings MD, Zhou Y, Mohammad-Qureshi SS, Bennett D, Pavitt GD. 2013. elF2B promotes elF5 dissociation from elF2*GDP to facilitate guanine nucleotide exchange for translation initiation. Genes \& Development 27: 2696-2707. doi: 10.1101/gad.231514.113.

Julien O, Kampmann M, Bassik MC, Zorn JA, Venditto VJ, Shimbo K, Agard NJ, Shimada K, Rheingold AL, Stockwell BR, Weissman JS, Wells JA. 2014. Unraveling the mechanism of cell death induced by chemical fibrils. Nature Chemical Biology 10:969-976. doi: 10.1038/nchembio.1639.

Kampmann M, Bassik MC, Weissman JS. 2013. Integrated platform for genome-wide screening and construction of high-density genetic interaction maps in mammalian cells. Proceedings of the National Academy of Sciences of USA 110:E2317-E2326. doi: 10.1073/pnas.1307002110.

Kampmann M, Bassik MC, Weissman JS. 2014. Functional genomics platform for pooled screening and generation of mammalian genetic interaction maps. Nature Protocols 9:1825-1847. doi: 10.1038/nprot.2014.103.

Kim HJ, Raphael AR, LaDow ES, McGurk L, Weber RA, Trojanowski JQ, Lee VM, Finkbeiner S, Gitler AD, Bonini NM. 2013. Therapeutic modulation of elF2 $\alpha$ phosphorylation rescues TDP-43 toxicity in amyotrophic lateral sclerosis disease models. Nature Genetics 46:152-160. doi: 10.1038/ng.2853.

Kimball SR, Fabian JR, Pavitt GD, Hinnebusch AG, Jefferson LS. 1998. Regulation of guanine nucleotide exchange through phosphorylation of eukaryotic initiation factor elF2alpha. Role of the alpha- and delta-subunits of eiF2b. Journal of Biological Chemistry 273:12841-12845. doi: 10.1074/jbc.273.21.12841.

Krishnamoorthy T, Pavitt GD, Zhang F, Dever TE, Hinnebusch AG. 2001. Tight binding of the phosphorylated subunit of initiation factor 2 (elF2) to the regulatory subunits of guanine nucleotide exchange factor elF2B is required for inhibition of translation initiation. Molecular and Cellular Biology 21:5018-5030. doi: 10.1128/MCB. 21.15.5018-5030.2001.

Lee YY, Cevallos RC, Jan E. 2009. An upstream open reading frame regulates translation of GADD34 during cellular stresses that induce elF2 phosphorylation. Journal of Biological Chemistry 284:6661-6673. doi: 10.1074/ jbc.M806735200.

Leegwater PA, Vermeulen G, Könst AA, Naidu S, Mulders J, Visser A, Kersbergen P, Mobach D, Fonds D, van Berkel CG, Lemmers RJ, Frants RR, Oudejans CB, Schutgens RB, Pronk JC, van der Knaap MS. 2001. Subunits of the translation initiation factor elF2B are mutant in leukoencephalopathy with vanishing white matter. Nature Genetics 29:383-388. doi: 10.1038/ng764.

Leitman J, Barak B, Benyair R, Shenkman M, Ashery U, Hartl FU, Lederkremer GZ. 2014. ER stress-induced elF2alpha phosphorylation underlies sensitivity of striatal neurons to pathogenic huntingtin. PLOS ONE 9:e90803. doi: 10.1371/journal.pone.0090803.

Li W, Wang X, van der Knaap MS, Proud CG. 2004. Mutations linked to leukoencephalopathy with vanishing white matter impair the function of the eukaryotic initiation factor 2B complex in diverse ways. Molecular and Cellular Biology 24:3295-3306. doi: 10.1128/MCB.24.8.3295-3306.2004.

Lu PD, Harding HP, Ron D. 2004. Translation reinitiation at alternative open reading frames regulates gene expression in an integrated stress response. The Journal of Cell Biology 167:27-33. doi: 10.1083/jcb.200408003.

Ma T, Trinh MA, Wexler AJ, Bourbon C, Gatti E, Pierre P, Cavener DR, Klann E. 2013. Suppression of elF2 $\alpha$ kinases alleviates Alzheimer's disease-related plasticity and memory deficits. Nature Neuroscience 16:1299-1305. doi: 10.1038/nn.3486.

Martin L, Kimball SR, Gardner LB. 2010. Regulation of the unfolded protein response by elF2B Isoforms. Journal of Biological Chemistry 285:31944-31953. doi: 10.1074/jbc.M110.153148.

Matheny CJ, Wei MC, Bassik MC, Donnelly AJ, Kampmann M, Iwasaki M, Piloto O, Solow-Cordero DE, Bouley DM, Rau R, Brown P, McManus MT, Weissman JS, Cleary ML. 2013. Next-generation NAMPT inhibitors identified by sequential high-throughput phenotypic chemical and functional genomic screens. Chemistry \& Biology 20: 1352-1363. doi: 10.1016/j.chembiol.2013.09.014.

Martinez Molina DM, Jafari R, Ignatushchenko M, Seki T, Larsson EA, Dan C, Sreekumar L, Cao Y, Nordlund P. 2013. Monitoring drug target engagement in cells and tissues using the cellular thermal shift assay. Science $\mathbf{3 4 1}$ : 84-87. doi: 10.1126/science.1233606.

Moreno JA, Halliday M, Molloy C, Radford H, Verity N, Axten JM, Ortori CA, Willis AE, Fischer PM, Barrett DA, Mallucci GR. 2013. Oral treatment targeting the unfolded protein response prevents neurodegeneration and clinical disease in prion-infected mice. Science Translational Medicine 5:206ra138. doi: 10.1126/scitranslmed. 3006767.

Moreno JA, Radford H, Peretti D, Steinert JR, Verity N, Martin MG, Halliday M, Morgan J, Dinsdale D, Ortori CA, Barrett DA, Tsaytler P, Bertolotti A, Willis AE, Bushell M, Mallucci GR. 2012. Sustained translational repression by elF2 $\alpha$-P mediates prion neurodegeneration. Nature 485:507-511. doi: 10.1038/nature11058. 
Nadif Kasri N, Nakano-Kobayashi A, Van Aelst L. 2011. Rapid synthesis of the X-linked mental retardation protein OPHN1 mediates mGluR-dependent LTD through interaction with the endocytic machinery. Neuron 72:300-315. doi: 10.1016/j.neuron.2011.09.001.

Novoa I, Zeng H, Harding HP, Ron D. 2001. Feedback inhibition of the unfolded protein response by GADD34mediated dephosphorylation of elF2alpha. The Journal of Cell Biology 153:1011-1022. doi: 10.1083/jcb.153.5.1011.

Oldfield S, Proud CG. 1992. Purification, phosphorylation and control of the guanine-nucleotide-exchange factor from rabbit reticulocyte lysates. European Journal of Biochemistry 208:73-81. doi: 10.1111/j.1432-1033.1992. tb17160.x.

Palam LR, Baird TD, Wek RC. 2011. Phosphorylation of elF2 facilitates ribosomal bypass of an inhibitory upstream ORF to enhance CHOP translation. The Journal of Biological Chemistry 286:10939-10949. doi: 10.1074/jbc. M110.216093.

Pavitt GD, Yang W, Hinnebusch AG. 1997. Homologous segments in three subunits of the guanine nucleotide exchange factor elF2B mediate translational regulation by phosphorylation of elF2. Molecular and Cellular Biology 17:1298-1313.

Ramage HR, Kumar GR, Verschueren E, Johnson JR, Von Dollen J, Johnson T, Newton B, Shah P, Horner J, Krogan NJ, Ott M. 2015. A combined proteomics/genomics approach links hepatitis $C$ virus infection with nonsensemediated mRNA decay. Molecular Cell 57:329-340. doi: 10.1016/j.molcel.2014.12.028.

Roy B, Vaughn JN, Kim BH, Zhou F, Gilchrist MA, Von Armin AG. 2010. The h subunit of elF3 promotes reinitiation competence during translation of mRNAs harboring upstream open reading frames. RNA 16:748-761. doi: 10.1261/rna.2056010.

Sekine Y, Zyryanova A, Crespillo-Casado A, Fisher PM, Harding HP, Ron D. 2015. Mutations in translation initiation factor identify the target of a memory-enhancing compound. Science Express. doi: 10.1126/science.aaa6986.

Sidrauski C, Acosta-Alvear D, Khoutorsky A, Vedantham P, Hearn BR, Li H, Gamache K, Gallagher CM, Ang KK, Wilson C, Okreglak V, Ashkenazi A, Hann B, Nader K, Arkin MR, Renslo AR, Sonenberg N, Walter P. 2013. Pharmacological brake-release of mRNA translation enhances cognitive memory. eLife 2:e00498. doi: 10.7554/ elife.00498.

Sidrauski C, McGeachy AM, Ingolia NT, Walter P. 2015. The small molecule ISRIB reverses the effects of elF2 $\alpha$ phosphorylation on translation and stress granule assembly. eLife 4:e05033. doi: 10.7554/eLife.05033.

Szamecz B, Rutkai E, Cuchalová L, Munzarová V, Herrmannová A, Nielsen KH, Burela L, Hinnebusch AG, Valášek L. 2008. elF3a cooperates with sequences $5^{\prime}$ of UORF1 to promote resumption of scanning by post-termination ribosomes for reinitiation on GCN4. Genes \& Development 22:2414-2525. doi: 10.1101/gad.480508.

Sokabe M, Fraser CS, Hershey JW. 2012. The human translation initiation multi-factor complex promotes methionyl-tRNAi binding to the 40S ribosomal subunit. Nucleic Acids Research 40:905-913. doi: 10.1093/nar/ gkr772.

Vattem KM, Wek RC. 2004. Reinitiation involving upstream ORFs regulates ATF4 mRNA translation in mammalian cells. Proceedings of the National Academy of Sciences of USA 101:11269-11274. doi: 10.1073/pnas. 0400541101.

Ventura A, Meissner A, Dillon CP, McManus M, Sharp PA, Van Parijs L, Jaenisch R, Jacks T. 2004. Cre-loxregulated conditional RNA interference from transgenes. Proceedings of the National Academy of Sciences of USA 101:10380-10385. doi: 10.1073/pnas.0403954101.

Wang G, Han T, Nijhawan D, Theodoropoulos P, Naidoo J, Yadavalli S, Mirzaei H, Pieper AA, Ready JM, McKnight SL. 2014. P7C3 neuroprotective chemicals function by activating the rate-limiting enzyme in NAD salvage. Cell 158: 1324-1334. doi: 10.1016/j.cell.2014.07.040.

Wek RC, Jiang HY, Anthony TG. 2006. Coping with stress: elF2 kinases and translational control. Biochemical Society Transactions 34:7-11. doi: 10.1042/BST20060007.

Williams DD, Price NT, Loughlin AJ, Proud CG. 2001. Characterization of the mammalian initiation factor elF2B complex as a GDP dissociation stimulator protein. Journal of Biological Chemistry 276:24697-24703. doi: 10.1074/jbc.M011788200.

Wiseman RL, Zhang Y, Lee KP, Harding HP, Haynes CM, Price J, Sicheri F, Ron D. 2010. Flavonol activation defines an unanticipated ligand-binding site in the kinase-RNase domain of IRE1. Molecular Cell 38:291-304. doi: 10.1016/j.molcel.2010.04.001.

Wortham NC, Martinez M, Gordiyenko Y, Robinson CV, Proud CG. 2014. Analysis of the subunit organization of the elF2B complex reveals new insights into its structure and regulation. FASEB Journal 28:2225-2237. doi: 10.1096/fj.13-243329.

Ye J, Kumanova M, Hart LS, Sloane K, Zhang H, De Panis DN, Bobrovnikova-Marjon E, Diehl JA, Ron D, Koumenis C. 2010. The GCN2-ATF4 pathway is critical for tumour cell survival and proliferation in response to nutrient deprivation. The EMBO Journal 29:2082-2096. doi: 10.1038/emboj.2010.81.

Zorn JA, Wells JA. 2010. Turning enzymes ON with small molecules. Nature Chemical Biology 6:179-188. doi: 10.1038/nchembio.318. 